\title{
V ISKANJU LASTNE IDENTITETE: ČEŠKI VIOLINISTI KOT GLAVNI TVORCI VIOLINIZMA NA SLOVENSKEM
}

\author{
MARUŠA ZUPANČIČ \\ Znanstvenoraziskovalni center SAZU, Ljubljana
}

Izvleček: V prispevku so obravnavani močni češki violinski vplivi, ki so v 19. pa tudi še v 20. stoletju krojili in soustvarjali slovensko zodovino violinizma ter vplivali na razvoj domačih simfoničnih orkestrov. Češki vplivi na Slovenskem so bili večplastni, najmočneje pa so bili izraženi $v$ pedagoški dejavnosti obravnavanega časa, saj je bil tedaj delež čeških violinskih pedagogov največji. K nam so razširili praško violinsko šolo, v 20. stoletju pa popularizirali slavno violinsko metodo Otakarja Ševčika, ki se še danes uporablja za poučevanje violine.

Ključne besede: violinizem na Slovenskem, glasba od 18. do 20. stoletja, češki in slovenski violinisti, violinska koncertna in pedagoška dejavnost na Slovenskem.

\begin{abstract}
This paper discusses the strong influence of Czech violinism of the eighteenth and twentieth centuries, which had formative importance for shaping the history of violinism in Slovenia and, consequently, a significant impact on the development of Slovenian symphonic orchestras. The features of the Czech school were manifold, although they were most pronounced in educational settings, because the number of Czech violin teachers was then at its peak. The Czech teachers introduced the Prague violin school, and in the twentieth century they also popularized Otakar Ševčik's renowned method, which remains in use in violin instruction to this day.
\end{abstract}

Keywords: violinism in Slovenia, eighteenth-century music, nineteenth-century music, twentiethcentury music, Czech and Slovenian violinists, violin concerts and violin pedagogy in Slovenia.

Ob proučevanju zgodovinskih vplivov kakega naroda je lahko določanje nacionalne pripadnosti zelo vprašljivo, saj rojstnega kraja niti danes ne moremo imeti za dokaz posameznikovega državljanstva, še manj pa narodnosti. Današnjih nacionalnih razmerij nikakor ne moremo prenašati v prejšnja stoletja, saj se je moderna zavest o nacionalni pripadnosti v glavnem prebudila šele v 19. stoletju, pa še v tem obdobju je ob tovrstnem določanju potrebna velika mera previdnosti. Na češkem ozemlju so velik del takratnega prebivalstva predstavljali Nemci, zato je določanje narodnosti na podlagi rojstnega kraja toliko bolj zapleteno. ${ }^{1}$ Ker pa je ob proučevanju vplivov kakega naroda na drugi narod prav vprašanje

1 Češka je imela že od srednjega veka naprej velik delež nemškega prebivalstva, čeprav je v drugi polovici 19. stoletja češko prebivalstvo postajalo številčnejše. V okviru monarhije bi lahko obe 
nacionalnosti zelo pomemben dejavnik, sem v okviru čeških violinskih vplivov upoštevala kraj glasbenikovega rojstva, geografsko področje glasbenega delovanja in šolanje znotraj praške violinske šole. ${ }^{2}$

Sodelovanje med Čehi in Slovenci je imelo že pred 19. stoletjem dolgo tradicijo, saj prvi izpričani kulturni stiki segajo v 14. stoletje. V drugi polovici 18. stoletja so bile okoliščine kulturnemu sodelovanju Čehov in Slovencev še posebej naklonjene. Do povezav med narodoma je prišlo predvsem v 19. stoletju, ko je začela Češka med Slovani v avstro-ogrski monarhiji pridobivati vedno večji ugled in vpliv. K povezovanju Slovanov v monarhiji je močno pripomogla ideja o slovanski vzajemnosti in solidarnosti, ki je navduševala tudi mnoge Slovence. Tovrstne ideje so se pojavile predvsem med kulturniki in znanstveniki, zato je večina stikov in povezav potekala v teh krogih. ${ }^{3}$ Močan val češke migracije, zlasti izobraženih glasbenikov in drugih čeških izobražencev na Slovensko, je korenito utrl pot nadaljnjemu razvoju glasbe pri nas in močno zaznamoval našo glasbenozgodovinsko pot, kar je seveda vplivalo tudi na sam razvoj violinizma pri nas.

Najzgodnejši češki violinski vplivi sežejo v pozno 18. stoletje. V arhivu frančiškanskega samostana v Novem mestu so se ohranili prepisi violinskih del dveh čeških skladateljev - Antonína Kammela (1730-1784) in Jana Křitla Vaňhala (1739$1813) .^{5}$ Pri obeh skladateljih gre večinoma za violinske duete, ki so zaradi violinskega znanja obeh skladateljev sicer komponirani v značilnem violinskem stilu, vendar pa ne vsebujejo zahtevnejših violinskih tehničnih prvin. Novomeški arhiv ima precej več ohranjenih violinskih del kot drugi slovenski glasbeni arhivi. Ob tem se nam zastavlja vprašanje o tamkajšnji violinski dejavnosti in o poteh, po katerih so tja pripotovala ohranjena violinska dela. Kot kaže, se ta v novomeškem frančiškanskem arhivu niso pojavila na-

narodni skupnosti (Nemce in Čehe) imeli za manjšini. Nemci so v letih 1848-1914 predstavljali več kot tretjino prebivalstva na Češkem in več kot četrtino prebivalstva na Moravskem (Marcela C. Efmertová, České země v letech 1848-1918, Praha, Nakladatelství Libri, 1998, str. 127-128).

2 Določanje potomcev praške violinske šole je večkrat težavno, saj iz arhivov mnogokrat ni razvidno glasbeno šolanje violinistov. Poleg tega so bili mnogi takratni violinisti potomci več violinskih šol, praška violinska šola pa se je razvila šele z ustanovitvijo praškega konservatorija leta 1811. Prvi violinski učitelj na praškem konservatoriju je bil Friedrich Wilhelm Pixis, ki velja tudi za ustanovitelja praške violinske šole. František Židek, Čeští houslisté tř́ století, Praha, Panton, 1979; Ratibor Budiš, Slavní čeští houslisté, Praha, Státní hudební vydavatelství, 1966; Ladislav Miranov, Metodika violine in viole I, Zagreb, Muzička naklada, 1964, str. 225-229; Robin Stowell, The Cambridge Companion to the Violin, Cambridge, Cambridge University Press, 1992, str. 64-96.

3 Boris Urbančič in Damjan Prelovšek, Češko-slovenski odnosi, Enciklopedija Slovenije 2, Ljubljana, Mladinska knjiga, 1988, str. 116-126: 117; Jonatan Vinkler, Posnemovalci, zavezniki in tekmeci: češko-slovenski in slovensko-češki kulturni stiki v 19. stoletju, Koper, Univerza na Primorskem [...], 2006; Boris Urbančič, Česko-slovínské kulturní styky, Praga, Euroslavica, 1995; Irena Gantar Godina, Neoslavizem in Slovenci, Ljubljana, Znanstveni inštitut Filozofske fakultete, 1994.

${ }^{4}$ Gl. Prilogo 1. Prim. Zdeňka Pilková, Antonín Kammel, Grove Music Online, http://nukweb.nuk. uni-lj.si:2151 (10. junij 2008).

5 Gl. Prilogo 1. Prim. Paul R. Bryan, Johann Baptist Vaňhal, Grove Music Online, http://nukweb. nuk.uni-1j.si:2151 (10. junij 2008). 
ključno, ampak so bila skrbno izbrana. Za to je zaslužen Čeh, pater Mavricij Poehm, ${ }^{6}$ ki ni bil le prepisovalec mnogih del, pač pa tudi navdušen zbiratelj različnih glasbenih del. ${ }^{7} \mathrm{~S}$ svojo široko razgledanostjo in poznavanjem glasbenega repertoarja je k nam prinesel mnogo violinskih del, s tem pa novomeškim glasbenikom omogočil izvajanje in spoznavanje sodobnega violinskega repertoarja. ${ }^{8}$

Razlogi za prihod Čehov na slovensko ozemlje so bili najrazličnejši. Mnogo čeških glasbenikov je zlasti v poznem 18. in zgodnjem 19. stoletju odhajalo v Italijo, ki je bila $\mathrm{v}$ tem času operno središče in sploh eno izmed najpomembnejših evropskih kulturnih središč. Ker je bilo potovanje $\mathrm{v}$ takratnih okoliščinah zelo naporno in tudi s finančnega vidika težko izvedljivo, si je mnogo glasbenikov med drugimi postojankami na poti za predah izbralo tudi Ljubljano ali kakšno drugo mesto na slovenskem ozemlju. Postanek so ponavadi izkoristili predvsem za koncertiranje ali kakšno podobno dejavnost, s katero so si povečali osebni proračun in si tako omogočili nadaljevanje poti. Najpogostejši razlog za migracijo Čehov na Slovensko so bile tudi večje možnosti za zaposlitev, saj je bila Češka v tistem času že polna lastnih in tujih uspešnih glasbenikov. Včasih so bili razlogi za naselitev pri nas povsem osebne narave, posledica tega pa poroka. Iz podobnih razlogov je k nam kot violinist prišel tudi František Josef Benedikt Dusík (1765-1816), ki se je po poroki s Kranjčanko Anno Fokke leta 1790 za nekaj časa ustalil v Ljubljani in leta 1794 postal prvi častni član Filharmonične družbe. Bil je vsestranski instrumentalist, ki je poleg violončela, flavte, klavirja in orgel obvladal tudi violino. ${ }^{9}$ Pri nas je kot violinist deloval v ljubljanski stolnici in na filharmoničnih prireditvah, kljub vsemu pa v violinski igri ni pustil večjih sledi. ${ }^{10}$ Napisal je tudi nekaj del za violino, vendar je večina izgubljenih ali pomanjkljivo ohranjenih. ${ }^{11}$ Močnejši češki violinski vplivi, katerih sledi so segale vse do 20. stoletja, izvirajo z začetka 19. stoletja in se odražajo na več ravneh. Najpomembnejšo vlogo je v tem času - predvsem za naslednje generacije - imela pedagoška dejavnost, v

6 Gl. Prilogo 1.

7 Janez Höfler, Glasbenozgodovinske najdbe XVIII. in XIX. stoletja v Novem mestu, Kronika: Časopis za slovensko krajevno zgodovino 15/3 (1967), str. 135-148; Tomaž Faganel, Glasba klasicizma v novomeških arhivih, 500 let Kolegiatnega kapitlja v Novem mestu. Dolenjski zbornik, ur. Stane Granda, Novo mesto, Dolenjska založba Novo Mesto, 1997, str. 215-221.

8 Med ohranjena violinska dela novomeškega frančiškanskega samostana spadajo tudi violinski koncerti, ki so še danes del violinskega koncertnega repertoarja, npr. koncerti Giovannija Batista Viottija in Pierra Rodeja, ki so bili v letih 1816-1871 tudi najpogosteje izvajani violinski koncerti na odru Filharmonične družbe. Koncertne sporede Filharmonične družbe v svoji Glasbeni zbirki hrani Narodna in univerzitetna knjižnica v Ljubljani. Gl. tudi Primož Kuret, Ljubljanska filharmonična družba 1794-1919, Ljubljana, Nova revija, 2005, str. 474-770.

9 O njegovi violinski dejavnosti pričajo njegovi solistični koncerti v Italiji, kjer je bil tudi koncertni mojster treh italijanskih gledališč (Mortare v Piemontu, San Benedetto v Benetkah ter Scala v Milanu).

${ }^{10}$ Gl. Prilogo 1. Prim. Stanislav Klíma, František Josef Benedikt Dusík, Hudební rozhledi 10 (1957), str. 995; Jitka Snižková, František Josef Benedikt Dusík, Muzikološki zbornik 26 (1990), str. 29-35: 30,32; František Benedikt Dusík, Simphonia grande in G, ur. Matjaž Barbo, Monumenta artis musicae Sloveniae 52, Ljubljana, ZRC SAZU, 2007, str. IX-XII.

${ }^{11}$ Dusíkova ohranjena violinska dela so Sonata za violino in klavir v F-duru; 2 veliki sonati za violino in klavir v B-duru in Es-duru (danes v Torinu, arhiv Accademie filarmonice); Sonata za violino in klavir op. 2 v C-duru. 
okviru katere so se oblikovala in razvijala zgodnja violinsko-pedagoška načela. Ena izmed prvih pedagoških ustanov je bila Javna glasbena šola, ustanovljena leta 1816, prvi učitelj pa Čeh Franc Sokol (1779-1822). ${ }^{12}$ Čeprav je bil predvsem uspešen klarinetist in se kot tak najpogosteje pojavlja v najrazličnejših virih, je poučeval tudi violino in še nekaj drugih instrumentov. ${ }^{13}$ Po smrti ga je nasledil Čeh Gašpar Mašek (1794-1873), kapelnik Filharmonične družbe in skladatelj. ${ }^{14}$ Maškova pedagoška obveznost je bila učence v štirih letih usposobiti v branju prima vista ne le pri klavirju, na orglah in pri petju, ampak tudi na violini. ${ }^{15}$ Šolski nadzorniki so močno kritizirali njegovo poučevanje, predvsem zaradi nepravilne drže violine, nečiste intonacije pri lestvicah in nemuzikalnega igranja njegovih učencev. Mašek se je branil, da je za nepravilno držo instrumenta kriva plahost učenca, svojo pedagoško usposobljenost pa dokazoval s pojasnilom, da poučuje po navodilih velikih mojstrov, na podlagi slik, ki prikazujejo pravilno držo violine in loka. ${ }^{16}$ Njegovo pojasnilo samo po sebi najbolje zrcali dejansko znanje takratnih violinistov pri nas, saj je bila prva generacija violinistov violinsko še zelo slabo podkovana. Kljub številnim kritikam na račun Maškovega slabega poučevanja violine je za nas pomembno njegovo edino znano violinsko delo Variacije za violino in klavir na temo Lucie Lamermoor, napisano leta 1840, saj predstavlja eno zgodnejših violinskih del, ki je nastalo na slovenskih tleh. ${ }^{17}$ Kljub temu da prvi učitelji violine zaradi površnega in zgolj elementarnega znanja niso mogli posredovati česa več od osnov violinske igre, se je stanje sčasoma izboljšalo, saj so k nam začeli prihajati vedno boljši češki violinisti. Eden takih je bil Čeh Anton (Antonín) Nedvěd (1829-1896), ${ }^{18}$ ki je leta 1858 prevzel mesto učitelja violine za obolelim Kamilom Maškom. Ta sicer ni poučeval violine, znano pa je, da je na številnih javnih nastopih nastopal kot violinist. ${ }^{19}$ Antonu Nedvědu je že v zgodnjem otroštvu odlično violinsko znanje posredoval izvrstni češki violinski pedagog Antonín Slavík (1782-1853), ki je vzgojil tudi enega največjih čeških violinistov - svojega sina Josefa Slavíka (1806-

${ }^{12}$ Sokol je ena izmed najstarejših rodbin v mestu Sadska na Češkem, saj se je prvi Sokol rodil že leta 1590 (podatke mi je prijazno posredoval gospod Martin Šulc). Arhivsko gradivo hranijo naslednje ustanove: Státní oblastní archiv Praha (SOA), Statní okresní archiv Nymburk (SOkA). Gl. tudi Prilogo 1.

${ }^{13}$ Dragotin Cvetko, Stoletja slovenske glasbe, Ljubljana, Cankarjeva založba, 1964, str. 144; Dragotin Cvetko, Zgodovina glasbene umetnosti na Slovenskem 2, Ljubljana, Državna založba Slovenije, 1959, str. 184; Peter von Radics, Die Geschichte der Philharmonischen Gesellschaft (1701-1907), rkp., Narodna in univerzitetna knjižnica v Ljubljani, str. 143; Cvetko Budkovič, Razvoj glasbenega šolstva na Slovenskem 1, Ljubljana, Znanstveni inštitut Filozofske fakultete, 1992, str. 25, 28-30, 43, 329, 347.

${ }^{14}$ Gl. Prilogo 1. Prim. Igor Grdina, Gašpar Mašek v navzkrižjih časa meščanov, Maškov zbornik, ur. Edo Škulj, Ljubljana, Družina, 2002, str. 17-26.

${ }^{15}$ Branka Rotar Pance, Gašpar Mašek - pedagog, Maškov zbornik, ur. Edo Škulj, Ljubljana, Družina, 2002, str. 51-58: 57.

${ }^{16}$ Viktor Steska, Iz slovenske glasbene prošlosti: Javna glasbena šola v Ljubljani (od leta 18161875), Cerkveni glasbenik 52 (1929), str. 83-86; C. Budkovič, nav. delo, str. 30-31.

${ }^{17}$ Note hrani Glasbena zbirka v Narodni in univerzitetni knjižnici.

${ }^{18}$ Gl. Prilogo 1. Prim. Engelbert Gangl, Anton Nedvěd: slovenski glasbenik, Dom in svet 11 (1898), št. 1 , str. $1-3$.

${ }^{19}$ Kamila Maška je violino poučeval oče Gašpar Mašek in odločilno vplival na razvoj njegove glasbene poti. B. Rotar Pance, nav. delo, str. 57. 
1833). ${ }^{20}$ Nedvěd je študij nadaljeval na praškem konservatoriju, kjer je bil učenec Moritza (Mořica) Mildnerja (1812-1865), ${ }^{21}$ enega glavnih tvorcev stare praške violinske šole, ki je kmalu zaslovela po vsem svetu. Nedvěd je s svojim dobrim znanjem lahko na nove generacije prenašal kakovostne osnove violinske igre, ki jih je dobil od svojih odličnih violinskih pedagogov. Poleg tega je vedel tudi, katere spremembe mora sprejeti šola, če želi doseči kakršenkoli napredek. Dotlej so violino in klavir poučevali izmenično po pet mesecev, Nedvěd pa je kmalu dosegel, da so pričeli omenjene instrumente poučevati strnjeno po celo leto.22 Čeprav je bila Javna glasbena šola prvi zavod, kjer je bil pouk violine vsem dostopen, na tem področju ni izpolnila začrtanih ciljev, niti ni dosegla višje kakovosti samega violinskega poučevanja. Razloge lahko iščemo predvsem v pomanjkljivi izobrazbi učiteljev: violina je bila navadno zgolj eden izmed mnogih instrumentov, ki so ga morali obvladati in kasneje poučevati. Tudi sama oblika izvajanja violinskega pouka je bila zgrešena, saj je ta potekal zgolj skupinsko. Ta praksa se je obdržala še lep čas tudi v drugih glasbenih šolah. Poleg tega violina v Javni glasbeni šoli prav gotovo ni bila mišljena kot instrument za izkazovanje virtuoznosti, temveč je zaradi svoje priročnosti služila bolj praktičnim namenom: kot pomoč pri intonaciji zbora ali zgolj za enostavno spremljavo.

V virtuoznem violinskem smislu je šola Filharmonične družbe močno napredovala, ko je med svoje učitelje violine začela sprejemati že priznane violiniste. Šola je leta 1826 ob uvedbi pouka violine za učitelja izbrala češkega violinista Josefa Beneša (17951873). ${ }^{23}$ Ta je močno preraščal okvire tedanjega violinskega diletantizma. O njegovi odlični tehniki še danes pričajo tako zapuščina njegovih pri nas ohranjenih violinskih del $^{24}$ kot takratne kritike, ki ga uvrščajo med odlične violinske virtuoze. ${ }^{25}$ Beneš je zapolnil mnoge vrzeli v našem takratnem glasbenem življenju, saj je deloval kot glasbeni in orkestrski direktor Filharmonične družbe, kot pedagog v zasebni violinski šoli ter kot koncertant in skladatelj. Komponiral je izključno violinska dela, ki jih je navadno na svojih koncertih tudi sam izvajal. Ko je leta 1829 odšel iz Ljubljane, so ga izvolili za častnega člana Filharmonične družbe. Istega leta je zaradi pomanjkanja sredstev propadla tudi violinska šola. Pouk violine je bil spet vzpostavljen leta 1848, instrument je poučeval Joseph Leitermeyer. Leta 1854 ga je nadomestil mladi češki violinist Jindřích

${ }^{20}$ Gl. Prilogo 1. Prim.Václav Čepelák in Bořivoj Mikoda, Josef Slavík: K 150. výročí narozenin velkého českého houslisty, Hořovice, Musejní odbor záv. klubu obch. tisk., 1956; Stanislav Václav Klíma, Josef Slavík (1806-1933): život a dílo velkého českého houslisty, Praha, Statní nakladatelství krasné literatury, hudby a umění (SNKLHU), 1956; Lev Vojtěch, Josef Slavík, Praha, Orbis, 1948.

${ }^{21}$ Gl. Prilogo 1. Prim. F. Židek, nav. delo, str. 81.

${ }^{22}$ C. Budkovič, nav. delo, str. 41.

${ }^{23}$ Gl. Prilogo 1. Prim. Barbara Boisits, Joseph Benesch, Österreichisches Musiklexikon 1, Wien, Österreichischen akademie der Wissenschaften, 2002, str. 133.

${ }^{24}$ Pri nas ohranjena Benešova dela so: Concertino, op. 14; Variations, op. 11; Variations brillantes, op. 12; Variations pour le Violon, op. 18; Variations pour le Violon, op. 19. Iz programskih listov je razvidno, da je v Ljubljani koncertiral še z mnogimi drugimi svojimi deli, ki so danes povsem neznana (Rondeau za violino; Variacije za violino na temo Santinelle; Rondo alla Pollaca za violino in orkester). Drugod po svetu je ohranjenih še nekaj njegovih violinskih del.

${ }^{25}$ Illyrisches Blatt (15. 11. 1828), št. 46, str. 184; Illyrisches Blatt (14. 4. 1820), št. 15, str. 57, 58; Illyrisches Blatt (9. 3. 1821), št. 10, str. 37, 38 . 
(Heinrich) Fiby (1834-1917). ${ }^{26}$ Ta je v Ljubljani deloval kot violinski pedagog, kot dirigent Filharmonične družbe in kot solist v Stanovskem gledališču. Že leta 1857 je postal ravnatelj mestne glasbene šole (Städtische Musikschule) v Znojmu na Češkem. Leta 1866 je začel na šoli Filharmonične družbe violino poučevati češki glasbenik Gustav Moravec, ${ }^{27}$ ki je šoli ostal zvest dolgih 48 let. Bil je uspešen pedagog, poleg violine je poučeval še klavir in petje, hkrati pa je v različnih komornih ansamblih igral violino in violo. Kmalu se mu je kot violinski pedagog pridružil Johann (Hans) Gerstner (1851-1939), ${ }^{28} \mathrm{~s}$ katerim se je leta 1871 začelo popolnoma novo obdobje slovenskega violinizma. Gerstner se je rodil v Žluticah na Češkem, kjer je dobil tudi prvo violinsko znanje pri Karlu Rohmu. ${ }^{29}$ Študij violine je nadaljeval na praškem konservatoriju pri dveh odličnih čeških violinistih - Mořicu Mildnerju in Antonínu Bennewitzu (1833-1926). ${ }^{30}$ Takoj po študiju je prišel v Ljubljano ter postal koncertni mojster v orkestru Deželnega gledališča in violinski pedagog na šoli Filharmonične družbe. Vsestransko je popestril ljubljansko glasbeno življenje in bil pobudnik mnogih tamkajšnjih glasbenih novosti. Od leta 1871, ko je prišel v Ljubljano, pa vse do propada Filharmonične družbe leta 1918 je med domačimi izvajalci izvedel približno osemdeset odstotkov vseh violinskih koncertov v Filharmonični družbi. ${ }^{31}$ Druge koncerte so izvajali njegovi učenci, kar pomeni, da bi bila brez Gerstnerja violinska poustvarjalna dejavnost v Ljubljani močno osiromašena. Gerstner je Ljubljani in njenemu glasbenemu dogajanju ostal zvest vse do svoje smrti, čeprav so mu v Kölnu in Augsburgu nekajkrat ponujali mesto koncertnega mojstra, in to pod boljšimi pogoji. Kot solist in koncertni mojster je pri Filharmonični družbi deloval 48 let in sodeloval na več kot 700 koncertih. Vodil je tudi mnoge komorne večere in igral prvo violino na 154 tovrstnih prireditvah. Violino je poučeval na desetih vzgojno-

${ }^{26}$ Gl. Prilogo 1. Prim. Tomáš Pšenička, Obrázky z historie: »Kdo byl Heinrich Fiby?«, Nové znojemské listy (10. 10. 1997), št. 1, str. 6; Jitka Štěpničková, Nahlédnutí do fondu musejní knihovny: Znovu o knihách a lidech, Znojemský region (15. 3. 1996), št. 2, str. 5; Jan Tomán, Hymnus na nekončneho - Heinrich, Znojemský týden (21. 10. 2002), št. 2, str. 14.

${ }^{27}$ Gl. Prilogo 1. Prim. C. Budkovič, nav. delo, str. 68.

${ }^{28}$ Gl. Prilogo 1. Prim. Laibacher Zeitung z datumi: 6. 2. 1867, 10. 12. 1867, 13. 11. 1871, 23. 11. 1874; P. Kuret, nav. delo, 2005, str. 236-238; C. Budkovič, nav. delo, str. 73, 74; Česko-slovenský hudební slovník osob a institucí, Praha, Statní hudební vydavatelství Praha, 1963, str. 365.

${ }^{29}$ Iz dostopnih virov je razvidno, da je bil Karl Rohm v tem času v Žluticah edini učitelj violine. Tam je vzgojil dva izvrstna violinista - Johanna (Hansa) Gerstnerja in Emanuela Wirtha (1842-1923). Slednji se je proslavil na Visoki šoli za glasbo v Berlinu. Sprva je bil asistent slavnega violinista Josepha Joachima, kasneje pa najboljši violinski profesor svoje generacije na Visoki šoli za glasbo v Berlinu. Kot violist je bil tudi član slavnega Joachimovega kvarteta. Prav Wirth je Gerstnerja navdušil za violino. Tako Gerstner kot Wirth sta bila takoj po Rohmovem glasbenem pouku sprejeta na praški konservatorij, kar priča o kakovosti Rohmovega violinskega poučevanja.

${ }^{30}$ Gl. Prilogo 1. Prim. Maruša Zupančič, Vpliv čeških violinistov na slovenske v prvi polovici 20. stoletja, Ljubljana, 2007, str. 19-20 (Univerza v Ljubljani, Filozofska fakulteta, diplomsko delo).

${ }^{31}$ Osemdeset odstotkov vseh violinskih koncertov v Filharmonični družbi je pomenilo 71 violinskih solističnih koncertov. Pri izračunu niso bili upoštevani mnogi komorni koncerti. 
izobraževalnih zavodih, ${ }^{32}$ na katerih je vzgojil na tisoče učencev. ${ }^{33}$ Poučeval je prvega uspešnega slovenskega violinista - Lea Funtka (1885-1965), ki svoje violinske kariere ni nadaljeval v rodni deželi, ampak se je takoj po študiju violine pri Hansu (J an, Hanuš) Sittu (1850-1922) ${ }^{34}$ v Leipzigu uveljavil na Finskem kot koncertni mojster Helsinške filharmonije, kasneje pa predvsem kot dirigent. ${ }^{35}$ Poleg Funtka je Gerstner poučeval tudi nekaj pomembnejših violinistov, ki so delovali na glasbenih ustanovah pri nas ali v tujini. ${ }^{36}$ Čeprav se Gerstner ni izrecno posvečal skladanju, je napisal - vsaj do sedaj edino znano delo - Romanco za violino in klavir, ki je izgubljena. ${ }^{37}$ Leta 1914 je prevzel vodstvo šole in na njej v težavnih časih ostal do leta 1919, ko je Filharmonična družba prenehala delovati. V Gerstnerjevi senci je v letih 1884-1888 poučeval violino tudi glasbenik Josef Sklenař, ki pa za seboj v violinskem smislu ni pustil vidnejših sledi.

Ustanovitev šole Glasbene matice leta 1882 imamo lahko za začetek oziroma rojstvo slovenskega violinizma. Že ob ustanovitvi te šole se je pokazal velik pomen Gerstnerjevega violinskega pedagoškega delovanja na šoli Filharmonične družbe, saj je kot prvi violinski učitelj na šoli Glasbene matice nastopil prav njegov učenec Anton Klein (1830-1901). Poleg tega je šola Glasbene matice od šole Filharmonične družbe prevzela Gerstnerjev violinski učni načrt. Glasbena matica je imela v prvih letih svojega obstoja veliko težav predvsem z violinskimi učitelji, ki jih je zaradi različnih razlogov neprestano menjavala. Tako se je od leta 1883 do leta 1888 zvrstilo kar nekaj čeških violinistov: Georg (Jurij) Stiaral $^{38}$ (Štaral, Staral), Josef Wiedmann, ${ }^{39}$ Ivan Drobeček (Drobiček, Dobriček), Antonín Sochor,$^{40}$ Anton Kučera, ${ }^{41}$ Ernest Eberhart. ${ }^{42} \mathrm{Na}$ Gerbičevo priporočilo

${ }^{32}$ Gerstner je violino poučeval na tehle vzgojno-izobraževalnih zavodih: na glasbeni šoli Filharmonične družbe, na zasebnem ženskem učiteljičču uršulink, na Mahrovi trgovski šoli, na otroškem inštitutu Waldherr in na dekliškem vzgojnem inštitutu Huth in Rehn.

${ }^{33}$ Gerstner je samo na glasbeni šoli Filharmonične družbe vzgojil preko 1000 učencev.

${ }^{34}$ Gl. Prilogo 1. Prim. F. Židek, nav. delo, str. 107.

${ }^{35}$ Gl. Prilogo 1. Prim. B.p., Heimische Künstler in der Fremde, Laibacher Zeitung 126 (1907), št. 260, str. 2426; B.p., Ljubljančan Leon Funtek - dirigent finske državne opere, Slovenec 69 (1941), št. 34a, str. 6; B.p., Heimische Künstler in der Fremde, Laibacher Zeitung 127 (1908), št. 33, str. 291; Otto Jauker, Herr Leo Funtek, Laibacher Zeitung 124 (1905), št. 72, str. 614; B.p., Heimische Künstler in der Fremde, Laibacher Zeitung 128 (1909), št. 247, str. 2214; B.p., Herr Konzertmeister Leo Funtek, Laibacher Zeitung 125 (1906), str. 2701; Primož Kuret, Slovensko-finski glasbenik Leo Funtek - ob stoletnici rojstva, Muzikološki zbornik 21 (1985), str. 61-69.

${ }^{36}$ Njegovi vidnejši učenci so bili Ernst Pfefferer, Friedrich Kautzky, Julius Klaudela, Anton Klein, Mitzi Schmidiger in Josip Čerin.

${ }^{37}$ Naslov dela je razviden iz programskega lista Filharmonične družbe, saj ga je Gerstner izvedel na enem izmed koncertov Filharmonične družbe.

${ }^{38}$ Gl. Prilogo 1. Prim. Vojenská hudba v kultuře a historii českých zemí, ur. Jitka Bajgarová, Praha, Etnologický ústav akademie věd České republiky, 2007, str. 260.

${ }^{39}$ Gl. Prilogo 1. Prim. Vojenská hudba, nav. delo, str. 261.

${ }^{40}$ Anton Sochor je mnogokrat nastopil tudi na čitalniških prireditvah.

${ }^{41}$ Čeprav je imel priporočila, da je odličen violinski učitelj, odboru Glasbene matice ni ustrezal. Gl. še Prilogo 1.

${ }^{42}$ Ernest Eberhart je na šolo Glasbene matice prišel poučevat po priporočilih Antonína Bennewitza. Ker je odboru grozil, da bo odšel, če mu ne povišajo plače, ga je ta odpustil. Čeprav si je Eberhart želel ostati na šoli Glasbene matice in sta se za to zavzemala tudi Zellner in Janušovsky, odbor 
je v šolskem letu 1888/1889 violino začel poučevati Čeh Vitězslav Roman Moser (1864-1939), bolj znan kot Viktor Moser. Violino je študiral pri Františku Neumannu v Sušicah in pri Ferdinandu Lachnerju ${ }^{43}$ v Pragi, poleg violine pa tudi kompozicijo v razredu Zdeňka Fibicha. Na šoli Glasbene matice je poučeval violino od leta 1888 do leta 1891 , ko je postal profesor violine na zagrebškem konservatoriju, kjer je ostal dvanajst let (1891-1903). Napisal je dvodelne Tehnične vaje za violino (Zagreb, 1894), štiridelno Teoretično praktično šolo za violino (Zagreb, 1895), Suito za violino in orkester (1887) in Rapsodijo za violino in klavir (1888). ${ }^{44}$ Njegovi učenci so v violinski igri uspešno napredovali, kar so potrjevale tudi naklonjene kritike nastopov in pohvale Moserja kot violinskega učitelja. Moser je leta 1889 ustanovil tudi godalni kvartet, ${ }^{45}$ s katerim je nastopal na čitalniških prireditvah. Po njegovem odhodu je Jan Lego ${ }^{46}$ priskrbel novega češkega violinista Hanu ša B andisa, s katerim odbor Glasbene matice ni bil zadovoljen, čeprav je Bandis predložil izvrstna spričevala in je odboru Glasbene matice v začetku zelo ustrezal. ${ }^{47}$ Njegovo mesto učitelja violine je prevzel slovenski violinist Karel Jeraj (1874-1951), ki je bil po materi češkega rodu. ${ }^{48}$ Kljub temu da je bil odbor Glasbene matice nad njim sprva zelo navdušen, je kmalu podvomil o njegovih korektnih pedagoških sposobnostih $^{49}$ in ga zaradi tega zamenjal s češkim violinistom Josipom Vedralom (1872-1929). ${ }^{50}$ Ta je z odliko diplomiral na praškem konservatoriju v razredu odličnega

Glasbene matice ni popustil (zapis seje, 2. 12. 1885, IIIa, v Glasbeni zbirki ga hrani Narodna in univerzitetna knjižnica v Ljubljani).

${ }^{43}$ Gl. Prilogo 1. Prim. F. Žídek, nav. delo, str. 110.

${ }^{44}$ Gl. Prilogo 1. Prim. Vlasta Bokůvková, 2 tvorby Zdeňka Fibicha a jeho soukromého žáka: V Zapadočeském muzeu se vzpomínalo na skladatele Viktorja Romana Moserja, Plzeňski deník (22. 6. 1999), št. 8, str. 19; F. Žídek, nav. delo, str. 117-118.

${ }^{45}$ V kvartetu so igrali Vitězslav Moser, Pavel Lozar, Alojzij Žebre in Ivan Pianecki.

${ }^{46}$ Jan Lego je imel velik vpliv na češko-slovenske kulturne stike. V letih 1857-1867 je bil zaposlen v Kamniku, Ljubljani in Trstu. Od leta 1874 je živel v Pragi. Bil je med ustanovitelji mnogih slovenskih kulturnih ustanov, med drugim tudi prve slovenske čitalnice. V Pragi je bil ustanovitelj češko-slovenskega društva, ki je bilo bolj podporne, saj se je posvečalo predvsem izdajanjem slovenskih knjig za mladino in slovenskih študentom v Pragi. Zavzemal se je tudi za razvoj slovenskega glasbenega življenja, na Češkem je širil slovensko pesem. Ob njegovi sedemdesetletnici ga je Ivan Hribar poimenoval za apostola slovensko-češke vzajemnosti in ga imenoval za častnega meščana Ljubljane. B. Urbančič, nav. delo, 1995, str. 24-26.

${ }^{47}$ Poročila Glasbene matice, 15. 10. 1892, str. 26; 1893/1894, str. 4 (v Glasbeni zbirki hrani Narodna in univerzitetna knjižnica v Ljubljani).

${ }^{48}$ Jerajeva mati je bila hčerka ustanovitelja godalnega kvarteta Raček iz Brna. Gl. Prilogo 1. Prim. M. Zupančič, nav. delo, str. 90.

${ }^{49} \mathrm{~V}$ najrazličnejših virih pravi razlog za Jerajev odpust ni omenjen, ker je šlo za vprašanje moralno neprimernega vedenja. Očitali so mu, da je njegov stik z učenkami Glasbene matice preveč intimen, da jim izkazuje svojo naklonjenost v samih prostorih Glasbene matice, in to pred drugimi mladimi učenkami, ki se mu zaradi tega posmehujejo. Vodstvo Glasbene matice se je balo, da bi zavod izgubil zaupanje staršev. Hkrati so Jeraju očitali tudi slabe učne rezultate. Pri tem je treba upoštevati dejstvo, da je bil Jeraj takrat star komaj 21 let in da so mu bile nekatere učenke po letih najbrž zelo blizu (zapis seje, 14. februar 1895). Po razpadu avstro-ogrske monarhije se je vrnil v Ljubljano in dolga leta uspešno deloval kot profesor violine na ljubljanskem konservatoriju ter s svojima hčerkama (Vido in Oli Jeraj) nastopal v Triu Jeraj.

${ }^{50}$ Gl. Prilogo 1. Prim. M. Zupančič, nav. delo, str. 69-70. 
češkega violinista Antonína Bennewitza. Na začetku je bil tudi koncertno zelo dejaven, na razvoj violinizma pri nas pa je štiriintrideset let vplival predvsem s svojim poučevanjem na različnih vzgojno-izobraževalnih zavodih. Njegovi učenci so bili: Ivan Trost, Žane Bajda, Josip Zupančič, Vilko Šušteršič, Albin Fakin, Albert Jermol, Žiga Vodušek, Mirko Dežela, Ivan Karlin, Niko Štritof in drugi. Zapustil je tudi nekaj skladb za violino in klavir ter kvartet violin. ${ }^{51}$

V začetku 20. stoletja je Glasbena matica pričela ustanavljati svoje podružnice po manjših slovenskih mestih. To je vplivalo na razvoj glasbe ter violinske igre v glasbeno manj razvitih mestih, kamor so prišli službovat tudi mnogi Čehi. Ena večjih in pomembnejših podružnic Glasbene matice je bila tržaška, ustanovljena leta $1909 .{ }^{52} \mathrm{~V}$ šolskem letu 1912/1913 je tam poučeval violino Čeh Petr Teplý (1871-1964), ${ }^{53}$ ki je že naslednje leto ustanovil ansambel violin, sestavljen iz boljših učencev. Ob začetku vojne, leta 1914, je morala večina tamkajšnjih učiteljev v vojsko, zato je violinski oddelek ostal brez učiteljev; pouk so začasno prekinili. Po vojni je poučevanje violinskega oddelka prevzel češki violinist Fran Topič, ki je zasedel tudi mesto ravnatelja. Topič je nadaljeval Teplýjeva prizadevanja in godalni orkester razširil na 35 članov. Oba sta poleg rednega poučevanja violine gojila tudi komorno glasbo. Najpomembnejši Topičev učenec je bil naš kasnejši violinski koncertant in pedagog Karlo Rupel, Teplý pa je s svojim poučevanjem poskrbel predvsem za tamkajšnji učiteljski podmladek, saj sta njegova učenca Avgust Ivančič in Vladimir Prinčič ${ }^{54}$ kasneje za kratek čas prevzela poučevanje na violinskem oddelku. Prav Prinčič je leta 1939 napisal Šest skladb za mlade violiniste s spremljavo klavirja. Glasbena matica v Trstu pa ni bila edina, ki je širila češke violinske vplive. Že leta 1887 je Arturo Vram (1860-1938) ${ }^{55}$ v Trstu ustanovil violinsko šolo (Liceo Musicale). Čeprav je bil Vram potomec dunajske violinske šole, je svoje učence poučeval po Ševčíkovi metodi in jo v Trst tudi prvi prinesel. ${ }^{56}$ Eden izmed njegovih najboljših učencev je bil Slovenec Fran Gulič (1901-1973), ${ }^{57}$ danes na Slovenskem skoraj povsem neznan. Gulič je nekaj časa poučeval violino tudi na Glasbeni matici v Trstu. Po violinskih osnovah pri Vramu je šolanje nadaljeval pri Otakarju Ševčíku in Janu Mařáku ${ }^{58}$ v Pragi. Po koncu študija je

${ }^{51}$ Malý svet (Pět skladeb pro housle a klavír); Scherzetto (kvartet violin), Novi akordi (1912); Andante (kvartet violin), Novi akordi (1914).

${ }^{52}$ Glasbena matica Trst je bila ustanovljena iz slovenskega pevskega in glasbenega društva Trst, uradno poimenovanje je doživela šele leta 1922.

${ }^{53}$ Gl. Prilogo 1. Prim. Jitka Bajgarová, Role vojenských hudeb v hudebním životě první Československé republiky, Vojenská hudba, nav. delo, str. 363-387: 372; Primož Kuret, Glasbena Ljubljana v letih 1899-1919, Ljubljana, Državna založba Slovenije, 1985, str. 136, 137, 143.

${ }^{54}$ Gl. Prilogo 1.Prim. Rado Hrovatin in Vladimir Prinčič, Slovenski biografski leksikon 2, Ljubljana, Slovenska akademija znanosti in umetnosti, 1933-1952, str. 584-585.

${ }^{55}$ Gl. Prilogo 1. Prim. Giuseppe Radole, Ricerche sulla vita musicale a Trieste (1750-1950), Trieste, Edizioni Italo Svevo, 1988, str. 61.

${ }^{56}$ Kako napreden je bil Vram, kaže prav uporaba te metode, saj so prvi zvezki Ševčíkove violinske metode $\mathrm{v}$ tem času šele nastajali.

${ }^{57}$ Podatke mi je v pogovoru 19. 7. 2008 prijazno posredovala Guličeva hčerka Giulliana Gulli. Gl. tudi Prilogo 1 in Giuseppe Radole, Le scuole musicali a Trieste e il conservatorio "Giuseppe Tartini”, Trieste, Edizione Italo Svevo, 1992, str. 84.

${ }^{58}$ Gl. Prilogo 1. Prim. F. Židek, nav. delo, str. 170-172. 
leta 1924 ustanovil zasebno glasbeno šolo, ki je bila specializirana za godala in klavir (Accademia musicale triestina). Njegov najboljši učenec je bil njegov sin, slavni violinist, Franco Gulli ${ }^{59}$ - poučeval ga je šestnajst let. Prav po Ševčíkovem zgledu je Gulič napisal violinsko metodično delo Didattici per picole violinisti, v devetih zvezkih. Učenec Artura Vrama je bil v Trstu tudi Karol Pahor, bolj znan kot skladatelj. Očitno je Ševčíkova violinska metoda tudi na Pahorja naredila močan vtis, saj je kasneje svoje violinske učence poučeval izključno po njej. ${ }^{60}$

Češki violinski pedagogi so delovali tudi v Gorici, kjer je leta 1907 Pevsko in glasbeno društvo Gorica postalo podružnica ljubljanske Glasbene matice. Vodil ga je češki glasbenik Josip Míchl, ki je poleg Čeha Lavrenca Kubišta poučeval tudi violino. Zaradi fašizma je tudi zapuščina začetkov goriške Glasbene matice skoraj popolnoma uničena, zato ni veliko podatkov o violinskih učiteljih. Češki violinisti so po manjših slovenskih mestih poučevali violino že pred ustanovitvijo Glasbene matice. Zaradi pomanjkljivih virov so podatki o njihovem glasbenem oziroma violinskem delovanju zelo skopi. Na osnovni šoli v Trnovem pri Ilirski Bistrici je od leta 1814 deloval Jan Slavík (1787-1842). ${ }^{61}$ Od leta 1823 je bil zasebni glasbeni učitelj v Vipavi, od leta 1833 je deloval v Črnem vrhu nad Idrijo, od leta 1838 pa v Postojni. Prav tam je v začetku 19. stoletja violino poučeval še en Čeh - Josef Procházka (Giuseppe Prohaska). Češki violinski vplivi so se v začetku 20. stoletja dotaknili tudi glasbenega življenja v Kranju. Od leta 1910 je tam poučeval violino Žiga (Sigmund) Polašek, ki je končal praški konservatorij. Leta 1912 je napisal Uspavanko za violino in klavir, leta 1913 pa je skupaj z Josipom Vedralom izdal 25 narodnih pesmi za violino in klavir.

Po koncu 1. svetovne vojne so se za razvoj in napredek violinizma začeli za nas popolnoma novi časi - violina je doživela svoj slovenski preporod. Proti koncu leta so se začele priprave na ustanovitev glasbenega konservatorija. Ideje so se uresničile že naslednje leto, obenem je nastalo tudi Orkestralno društvo. Češki violinski vplivi so v tem obdobju doživeli svoj višek in ključno zaznamovali vse prihodnje slovenske koncertne violiniste in pedagoge. Leta 1918 je postal učitelj violine na šoli Glasbene matice v Ljubljani Čeh Richard Zíka (1897-1947), ${ }^{62}$ ki je bil tudi koncertni mojster Slovenskega narodnega gledališča. Pri nas je z ustanovitvijo Zíka kvarteta leta 1920 začel gojiti profesionalno komorno poustvarjanje. Napisal je tudi 6 capricciev za violino solo. Zagotovo pa je slovenski violinizem v 20. stoletju najbolj zaznamoval Čeh Jan Šlaís (1893-1975).63 Njegovo glasbeno življenje je bilo zelo bogato, v večini ga je posvetil prav poučevanju violine pri nas. Na praškem konservatoriju je bil učenec Štěpána Suchýja, ${ }^{64}$ pouk Otakarja Ševčíka ${ }^{65}$ pa je obiskoval na njegovi mojstrski šoli v Pragi. Šlaísov prihod v Ljubljano je

\footnotetext{
${ }^{59}$ Gl. Prilogo 1.

${ }^{60}$ Te podatke mi je posredoval moj ded Vilko Zupančič, ki je bil Pahorjev učenec violine in njegov sorodnik po veji rodbine Sosič iz Opčin pri Trstu.

${ }^{61}$ Gl. Prilogo 1. Prim. Cvetko Dragotin, Jan Slavík, Slovenski biografski leksikon 3, Ljubljana, Slovenska akademija znanosti in umetnosti, 1960-1971, str. 360.

${ }^{62}$ Gl. Prilogo 1. Prim. M. Zupančič, nav. delo, str. 79-80.

${ }^{63}$ Gl. Prilogo 1. Prim. M. Zupančič, nav. delo, str. 76-78.

${ }^{64}$ Gl. Prilogo 1. Prim. M. Zupančič, nav. delo, str. 43.

${ }^{65}$ Gl. Prilogo 1. Prim. M. Zupančič, nav. delo, str. 20-42.
} 
bil za slovenski violinizem izrednega pomena. Na konservatoriju je ustanovil violinski oddelek, učne načrte pa je izdelal na podlagi Ševčíkove tehnike. Bistveno je sodeloval pri postopnem uvajanju študija violine na visokošolski stopnji. Njegovo uspešno delo, ki je pri nas trajalo skoraj petindvajset let, njegov izredni pedagoški dar in široki umetniški nazori so dali obsežne rezultate. Položeni so bili temelji za razvoj slovenskega violinizma. V času svojega bivanja in poučevanja v Ljubljani je Šlaís tudi plodno koncertiral - solistično in komorno. Veliko je nastopal s svojo ženo Růženo Šlaísovo in v Ljubljanskem komornem duu s pianistom Antonom Trostom. Ustvaril je skoraj vse uspešne slovenske violiniste tega obdobja, to so bili: Karlo Rupel ${ }^{66}$ Leon Pfeifer, ${ }^{67}$ Albert (Ali) Dermelj, ${ }^{68}$ Vida Jeraj Hribar, ${ }^{69}$ Uroš Prevoršek, ${ }^{70}$ Kajetan Burger, Fran Stanič ${ }^{71}$ Jelka Stanič, ${ }^{72}$ Vinko Šušteršič, Francka Ornik Rojc ter drugi. Poleg Šlaísa in drugih čeških violinistov na Slovenskem so na razvoj violinizma pri nas močno vplivali tudi drugod delujoči češki violinisti, h katerim so pred drugo svetovno vojno odhajali študirat mnogi Slovenci. Med pomembnejšimi je bil Václav Huml, ${ }^{73}$ ki je deloval v Zagrebu in poučeval celo vrsto slovenskih violinistov. Huml je bil tako kot Šlaís Ševčíkov učenec in odličen violinist, svoje življenje je posvetil predvsem violinskemu poučevanju. Iz njegovega razreda je izšlo ogromno odličnih violinistov iz celotne Federativne republike Jugoslavije, tudi iz Slovenije. Med njimi so bili: Albert Dermelj, Karlo Sancin ${ }^{74}$ Fani (Fanika, Frančiška, Fany, Nada) Brandl (Pelikan, Jevđenijević, Vorkapić), ${ }^{75}$ Francka Ornik Rojc, Karlo Rupel, Jelka Stanič in Miran Viher. ${ }^{76}$ Nekateri od teh so se violinsko izpopolnjevali še pri drugih čeških violinistih, ki so delovali drugod po Evropi. Karlo Rupel je na izpopolnjevanje odšel na Ševčíkovo mojstrsko violinsko šolo v Písek, kjer je ostal eno leto. Leon Pfeifer se je v letih 1933-1935 izpopolnjeval na mojstrski violinski šoli praškega konservatorija v razredu slavnega Ševčíkovega učenca Jaroslava Kocíana. ${ }^{77}$ Miran Viher, pri nas slabo znan violinist, ki je kasneje zaradi političnih razlogov zapustil domovino, je študiral pri slavnem virtuozu Váši Př́hodi ${ }^{78}$ v Münchnu; uspešno umetniško pot violinista in komponista je do svoje smrti nadaljeval v ZDA. Kot

\footnotetext{
${ }^{66}$ Gl. Prilogo 1. Prim. M. Zupančič, nav. delo, str. 96-109.

${ }^{67}$ Gl. Prilogo 1. Prim. M. Zupančič, nav. delo, str. 94-95.

${ }^{68}$ Gl. Prilogo 1. Prim. M. Zupančič, nav. delo, str. 110-111.

${ }^{69}$ Gl. Prilogo 1. Prim. M. Zupančič, nav. delo, str. 90-93.

${ }^{70}$ Gl. Prilogo 1. Prim. Rado Hrovatin, Uroš Prevoršek, Slovenski biografski leksikon 2, Ljubljana, Slovenska akademija znanosti in umetnosti,1933-1952, str. 569.

${ }^{71}$ Gl. Prilogo 1. Prim. Rafael Ajlec, Fran Stanič, Slovenski biografski leksikon 3, Ljubljana, Slovenska akademija znanosti in umetnosti, 1960-1971, str. 437-438.

72 Gl. Prilogo 1. Prim. M. Zupančič, nav. delo, str. 120-124.

${ }^{73}$ Gl. Prilogo 1. Prim. M. Zupančič, nav. delo, str. 53-68.

${ }^{74}$ Gl. Prilogo 1. Prim. M. Zupančič, nav. delo, str. 80-82.

${ }^{75}$ Gl. Prilogo 1. Prim. M. Zupančič, nav. delo, str. 83-89.

${ }^{76}$ Gl. Prilogo 1. Prim. M. Zupančič, nav. delo, str. 107-111.

77 Gl. Prilogo 1. Prim. M. Zupančič, nav. delo, str. 48-52.

${ }^{78}$ Gl. Prilogo 1. Prim. M. Zupančič, nav. delo, str. 44-47.
} 
mnogo naših violinistov je na praškem konservatoriju študiral tudi Taras Poljanec, ${ }^{79}$ in sicer pri Rudolfu Reissigu. ${ }^{80}$ Svojo glasbeno pot je zatem uspešno nadaljeval v Mariboru.

Češka migracija v slovenske dežele ni vplivala samo na pedagoško dejavnost, ampak je začrtala tudi smernice delovanju Slovenske filharmonije in sploh močno vplivala na razvoj orkestrov pri nas. V orkestru Dramatičnega društva so delovali trije vidnejši češki glasbeniki: Hilarij Beníšek, Václav Talích ${ }^{81}$ in Cyril Metoděj Hrazdira. ${ }^{82}$ Talícha je na priporočila mnogih slovenskih glasbenikov, ki so študirali na praškem konservatoriju, v Ljubljano na mesto kapelnika povabila Glasbena matica. Talích, učenec Jana Mařáka in Otakarja Ševčíka, je pred prihodom v Ljubljano deloval kot koncertni mojster v Berlinski filharmoniji ${ }^{83}$ in orkestru mestne opere v Odesi. Zatem je eno leto prebil v Tbilisiju kot primarij godalnega kvarteta, učitelj violine ter kot dirigent v orkestru mestnega gledališča. Zaradi tamkajšnjih političnih nemirov se je leta 1906 vrnil v Prago. $\mathrm{V}$ tem času je že spoznal, da ga bolj kot violinsko poustvarjanje privlači dirigiranje, vendar so bila v Pragi vsa vidnejša umetniška mesta zasedena. Čeprav je dobil nekaj manjših priložnosti, se je v želji po samostojnem delu leta 1908 odzval povabilu Glasbene matice, naj v Ljubljani nastopi kot dirigent novoustanovljene Slovenske filharmonije. V kratkem času mu je uspelo spraviti orkester na zavidljivo raven, to pa je privedlo do sprememb, ki so ključno vplivale na nadaljnji razvoj violinizma na Slovenskem. Zaradi popularnosti Talíchovega orkestra so takratne različne glasbene vzgojno-izobraževalne ustanove začele načrtno vzgajati podmladek za potrebe novoustanovljenega orkestra. Iz Prage je Talích pripeljal tudi violinista Jana Rezka. ${ }^{84}$ Rezek, ki je na svojih koncertih igral najtežja dela violinskega solističnega repertoarja in dobival odlične kritike, je kratek čas celo poučeval violino na šoli Glasbene matice. Talích je ljubljansko glasbeno življenje popestril tudi z ustanovitvijo godalnega kvarteta, v katerem je poleg Čehov Jana Rezka, Karla Kučere in Edvarda Bíleka sam igral violo. V manj kot dveh letih so izvedli okoli 50 koncertov, kar je nedvomno popestrilo ljubljansko glasbeno življenje. Vendar je Talích kmalu ugotovil, da zaradi pogostih medsebojnih sporov, izvajanja drugorazrednega repertoarja in glasbeno zanj še vedno zaspanega okolja, kot dirigent stagnira. Zavedal se je tudi, da mu kot violinistu za dirigiranje manjka teoretičnega znanja. Odločil se je za študij dirigiranja na glasbenem konservatoriju v Leipzigu pri največjih dirigentih tistega časa. V Ljubljano se je vrnil leta 1911. Čeprav se je težko sprijaznil z ozkim glasbenim krogom delovanja, je imel do svoje druge domovine poseben odnos že zaradi svoje žene, Slovenke Vide Prelesnik. Ko je Ljubljano dokončno zapustil, se je število članov orkestra močno zmanjšalo. Orkester je prevzel Čeh Petr Teplý.

${ }^{79}$ Gl. Prilogo 1. Prim. Rado Hrovatin, Taras Poljanec, Slovenski biografski leksikon 2, Ljubljana, Slovenska akademija znanosti in umetnosti, 1933-1952, str. 437-438.

${ }^{80}$ Gl. Prilogo 1.

${ }^{81}$ Gl. Prilogo 1. Prim. Otakar Šourek, Václav Talich-Soubor statí o životě a práci, Praha, Hudební matice umělecké besedy, 1943, str. 13-77.

${ }^{82}$ Gl. Prilogo 1.

${ }^{83}$ Berlinska filharmonija je $\mathrm{v}$ tistem obdobju delovala pod taktirko slovitega dirigenta Arthura Nikischa.

${ }^{84}$ Jan Rezek je bil na začetku svojega bivanja v Ljubljani tudi Talíchov sostanovalec. Milan Kuna, Václav Talích a Lublaň, Hudební věda 20 (1983), str. 344-352: 348. 
Češko-slovenski glasbeni stiki so na ljubljanske koncertne odre pripeljali tudi slavne češke violiniste, ki so na svojih koncertih navadno izvajali tudi lastna violinska dela ter tehnično najtežja dela iz violinskega repertoarja. V kritikah so bili tako kot povsod drugod po svetu deležni največjih superlativov v smislu violinske virtuoznosti, žlahtnosti tona ter ganljive interpretacije. Nekateri izmed njih so bili še iz časa študija na praškem konservatoriju stari znanci mnogih čeških violinskih pedagogov, ki so poučevali pri nas. Tako so naši pedagogi prihajali v stik z novostmi, kasneje pa so lahko prav zaradi takšnih poznanstev priporočali svoje študente za nadaljnji študij. Najpomembnejši takšni koncertanti so bili Leopold Jansa, František Ondříček, Jan Kubelík, Váša Příhoda, Jaroslav Kocían in drugi.

Češki violinski vplivi so bili večji in močnejši, kot se jih zavedamo in jih priznavamo. Njihov prispevek k razvoju violinizma pri nas je bil ogromen. V violinski pedagogiki so opravili pionirsko delo, koncertne programe so zapolnili tudi z violinskim koncertnim repertoarjem ter omogočili, da je bil tudi slovenski narod v stiku s takrat najuspešnejšimi češkimi violinskimi metodami, ki so osvojile violiniste povsod po svetu. Največji pečat je pri nas v 19. stoletju s svojimi violinskimi potomci vtisnil Antonín Bennewitz, znan predvsem kot eden izmed glavnih tvorcev stare praške violinske šole, ki je dala največje violinske virtuoze in pedagoge tistega časa. Eden takih je bil tudi Bennewitzev učenec Otakar Ševčík, ki je v prvi polovici 20. stoletja močno zaznamoval nadaljnji razvoj našega violinizma. Preko njegovih violinskih »misijonarjev« se je k nam razširila njegova uspešna violinska didaktična metoda, ki je močno vplivala tudi na nastanek mnogih slovenskih violinskih metod. ${ }^{85}$ Te so se v mnogih primerih zgledovale prav po Ševčíkovi, ki je med violinskimi pedagogi v uporabi še danes. Vendar na razvoj violinizma ni vplivala samo njihova pedagoška dejavnost, mnogi češki violinisti in skladatelji so ogromno prispevali tudi k nastajanju našega violinskega repertoarja. ${ }^{86} \mathrm{~S}$ svojim delom so spodbujali tudi naše skladatelje, da so s svojimi kompozicijami prispevali k obogatitvi violinskega repertoarja. V mnogih violinskih delih čeških skladateljev ne smemo iskati zgolj izvirnega glasbenega materiala, saj skladbe nemalokrat skrivajo tudi vplive in violinske manire slavnih violinskih sodobnikov virtuozov, ki so z novostmi in neverjetno violinsko tehniko navdušili takratni glasbeni svet. ${ }^{87}$ Te novosti so se dotaknile tudi mnogih violinskih skladateljev, ki so ustvarjali pri nas. Tako so se k nam posredno prenesle violinske manire od drugod in sooblikovale nadaljnji razvoj našega violinizma. Velik pomen čeških violinistov na Slovenskem je treba iskati tudi v ustanavljanju slovenskih orkestrov, ki so bili v

${ }^{85}$ Fran Gulič (Didattici per picole violinisti, 9 zvezkov, edizioni Curci); Adolf Grömbing (Osnovna violinska šola, 1924); Karlo Rupel (Tehnika loka, 1949); Fran Stanič (Tehnične vaje za violino I (ok. 1941), Violinska šola (1943), Melodične etude za violino s spremljavo klavirja I (prva lega), II A (lege), II B (menjava leg); Violinska tehnika za srednjo in visoko stopnjo: Vaje za vsak dan (1960).

${ }^{86}$ Češka violinska dela, ki so se ohranila ali pa nastala pri nas: Josef Beneš, Concertino, op. 14, Grandes Variations, op. 11, Variations brillantes, op. 12, Variations pour le violon, op. 18, Variations pour le violon, op. 19; Gašpar Mašek, Variacije za violino in klavir na temo Lucie Lamermoor; Anton Foerster, Sonatina za violino in klavir, Domačinke za 3 violine in klavir; Hans Gerstner, Romanca za violino in klavir; Josip Vedral, Pro malý svět - 5 skladeb pro housle a klavir; Josef Procházka, Balada, op. 8, Dvě nokturna, op. 2.

${ }^{87}$ Značilen primer je vpliv igre in del Niccolòja Paganinija na violinska dela Josefa Beneša. 
svojih zgodnjih začetkih večinsko sestavljeni iz čeških glasbenikov. Uspešnost orkestrov je vplivala tudi na nastanek mnogih slovenskih orkestralnih kompozicijskih novitet, ki so začele pisati tudi slovensko glasbeno zgodovino. Danes imamo po svetu in doma ogromno uspešnih slovenskih violinistov, ki delujejo bodisi kot koncertanti, koncertni mojstri ali kot uspešni in iskani violinski pedagogi ${ }^{88}$ In prav vsakega od njih so vsaj deloma zaznamovali češki violinisti. Danes pa naši uspešni violinisti puščajo svoje sledi v delu novih in novih generacijah violinistov - slovenskih in tujih.

${ }^{88}$ Najbolj znani slovenski violinisti so: Igor Ozim, Primož Novšak, Gorjan Košuta, Mile Kosi, Črt Šiškovič, Miha Pogačnik, Dejan Bravničar, Miran Kolbl, Rok Klopčič, Tomaž Lorenz, Volodja Balžalorsky, Monika, Olga in Sabina Skalar ter drugi. 


\section{Priloga 1}

\section{ABECEDNI SEZNAM OBRAVNAVANIH ČEŠKIH IN SLOVENSKIH VIOLINISTOV}

Josef Beneš se je rodil leta 1795 v Batelovu na Češkem. S svojim glasbenim šolanjem je začel leta 1812 v mestu Potěhy in nadaljeval na Dunaju pri violinistu Martinu Schlessingerju. Igral je v gledaliških orkestrih v Badnu in Bratislavi. Leta 1823 je postal orkestrski direktor in violinski učitelj Filharmonične družbe v Ljubljani. Po odhodu iz Ljubljane leta 1829 je do leta 1867 deloval kot član dunajske dvorne kapele in prevzel mesto namestnika direktorja gledališča Hofburg (Hofburg Theater) na Dunaju. Leta 1824 je skupaj z Eduardom Jaellom izročil diplomo častnega člana Filharmonične družbe slavnemu violinistu Niccolòju Paganiniju. Umrl je leta 1873 v Ortu.

Antonín (Anton) Bennewitz se je rodil leta 1833 v mestu Přívaty na Češkem. V letih 1846-1852 je študiral violino na praškem konservatoriju v razredu Moritza Mildnerja. Po končanem študiju je bil osem let koncertni mojster v orkestru Stanovskega gledališča v Pragi. V klavirskem triu je igral skupaj z Bedříchom Smetano in violončelistom Františkom Hegenbartom. Leta 1861 je postal koncertni mojster v orkestru Mozarteuma v Salzburgu. Od leta 1863 je deloval kot kraljevi komorni glasbenik in kot drugi koncertni mojster dvorne opere v Stuttgartu. Leta 1866 je postal profesor na praškem konservatoriju, kasneje tudi njegov vodja. Ustvaril je vrsto odličnih violinistov, ki so nadaljevali tradicijo praške violinske šole. Umrl je leta 1926 v mestu Doksy.

Fani (Frančiška) Brandl se je rodila leta 1899 v Mariboru. Violino se je začela učiti s sedmimi leti pri zasebni učiteljici. Šolanje je nadaljevala na glasbeni šoli nemškega Filharmoničnega društva pri violinskem in klavirskem pedagogu Alfredu Klietmannu, ki je bil Ševčíkov učenec. V letih 1917-1919 je študirala violino pri znanem pedagogu Arnoldu Roséju na konservatoriju na Dunaju, pozneje pa še pri Václavu Humlu na Zagrebški glasbeni akademiji. Leta 1929 je skupaj s Hildo Folger in Herto Reiss ustanovila Brandl trio in z njima dolga leta uspešno nastopala. Kmalu po vojni je organizirala Mariborski trio, v katerem sta igrala še violončelist Oton Bajde in pianist dr. Roman Klasinc. Obenem je bila še članica Rusy tria (poleg nje in pianistke Magde Rusy je v njem igrala violončelistka Rosemarie Franz) in Slovenskega komornega tria (v njem sta bila še violončelist Oton Bajde in pianist Marijan Lipovšek). V teh komornih sestavih je pogosto nastopala pri nas in v tujini. Zaradi poškodbe roke je leta 1964 prenehala igrati. Zasebno je poučevala vrsto znanih mariborskih glasbenikov, med njimi dr. Romana Klasinca, Eriko in Hinka Druzovića, Francko Ornik in Draga Marija Šijanca. Leta 1965 je postala častna članica Zveze glasbenih umetnikov Jugoslavije, leta 1966 društva slovenskih skladateljev, leta 1992 pa je v Ljubljani prejela Bettetovo nagrado. Umrla je leta 1999, stara 100 let.

Albert Dermelj se je rodil leta 1912 v Ljubljani. Leta 1936 je končal konservatorij v razredu Jana Šlaísa. Študij je nadaljeval na Visoki šoli državne glasbene akademije v Zagrebu pri prof. Václavu Humlu. Na poustvarjalnem področju je kmalu po diplomi zasedel vodilno mesto koncertnega mojstra, sprva v opernem, nato v radijskem orkestru ter orkestru Slovenske filharmonije. Nastopal je tako solistično kot v mnogih komornih sestavih. Za svoje delo je prejel Betettovo nagrado, Društvo glasbenih pedagogov pa ga je imenovalo za častnega člana. Umrl je leta 1986. 
František Josef Dusík (Franz Benedikt Dussek) se je rodil leta 1765 v Časlavu. Obvladal je klavir, violončelo in violino. Leta 1790 je prišel v Ljubljano, kjer je kot violinist deloval v ljubljanski stolnici, na prireditvah Filharmonične družbe in v Stanovskem gledališču. Po obdobju v Ljubljeni je bil deloval kot koncertni mojster v več italijanskih gledališčih. Bil je tudi plodovit skladatelj. Napisal je tudi nekaj violinskih skladb, ki so pomankljivo ohranjene. Umrl je po letu 1816.

Jindř́ích Fiby se je rodil leta 1834 na Dunaju, kjer je končal konservatorij. Takoj po konservatoriju je postal pedagog in dirigent Filharmonične družbe v Ljubljani. Kmalu se je prijavil na mesto ravnatelja glasbene šole v Znojmu, kjer je bil izbran izmed 30 kandidatov. 1. 11. 1857 je nastopil službo ravnatelja znojemske glasbene šole, kjer je deloval 45 let. Večina njegovih skladb je bilo pred vojno shranjenih v znojemskem Musikvereinu, nekatere koncertne skladbe pa so shranjene v arhivu mestne vojaške glasbe. Umrl je leta 1917 v Znojmu, pokopan je na tamkajšnjem pokopališču.

Leo Funtek se je rodil leta 1885 v Ljubljani. Na šoli Glasbene matice ga je klavir poučeval Karel Hoffmeister, na šoli Filharmonične družbe pa Josef Zöhrer. Violino se je učil na šoli Filharmonične družbe pri Hansu Gerstnerju. Leta 1903 je opravil sprejemni izpit na leipziškem konservatoriju in bil sprejet v razred Hansa Sitta. Leta 1906 je kot koncertni mojster helsinškega orkestra nasledil Willya Burmestra. Med prvo svetovno vojno je bil koncertni mojster v Stockholmu. Po vojni se je vrnil na Finsko, kjer je deloval kot koncertni mojster, dirigent, korepetitor, pedagog in skladatelj. Umrl je leta 1965 v Helsinkih.

Johann (Hans) Gerstner se je rodil leta 1851 v Žluticah na Češkem, kjer je dobil prvo glasbeno in violinsko znanje pri Karlu Rohmu. V letih 1864-1870 je študiral violino na praškem konservatoriju v razredu Moritza Mildenrja in Antonína Bennewitza. V času študija je igral v Bennewitzovem kvartetu. Leta 1871 je prišel v Ljubljano, kjer se je zaposlil kot dirigent Deželnega gledališča in kot učitelj violine na šoli Filharmonične družbe. Koncertiral je tako solistično kot tudi v komornih zasedbah. 48 let je poučeval violino na različnih vzgojno-izobraževalnih zavodih, zasebno pa celo do 83. leta starosti. Leta 1914 je prevzel vodstvo šole in koncertov Filharmonične družbe in to funkcijo opravljal do leta 1919. Umrl je leta 1939 v Ljubljani.

Fran Gulič se je rodil leta 1901 v Trstu. Njegov prvi violinski učitelj je bil Arturo Vram. Študij violine je nadaljeval pri Ševčíku in Mařáku v Pragi. Diplomiral je tudi na glasbenem konservatoriju Rossini v Pesari in na glasbenem konservatoriju G. B. Martini v Bologni. Magistriral je na glasbenem konservatoriju Cherubini v Firencah. Leta 1924 je ustanovil zasebno glasbeno šolo, ki je bil specializirana za godala in klavir. Poleg sina Franca Gullija je violinsko igro poučeval tudi vnuka Federica Agostinija, ki je danes prav tako uspešen violinist in deluje kot koncertant in profesor violine na eni izmed univerz v ZDA. Gulič je umrl leta 1973 v Trstu.

Franco Gulli se je rodil leta 1926 v Trstu. Šestnajst let ga je violino poučeval njegov oče Fran Gulič. Zatem je študij violine nadaljeval pri Arrigu Seratu in Josephu Szigetiju. Solistično je igral z najboljšimi orkestri in dirigenti. Kot komorni glasbenik je nastopal s svetovno priznanimi glasbeniki. Violino je poučeval na Univerzi v Indiani ter zapustil vrsto zvočnih posnetkov. Umrl je leta 2001 v ZDA. 
Cyril Metoděj Hrazdira se je rodil leta 1868 v mestu Rajcí nad Svitavou. Bil je znana osebnost ostravskega glasbenega življenja, saj je ustanovil in vodil zbor. V letih 1891-1898 je bil vodja zbora v poljski Ostravi. Umrl je leta 1926 v Brnu.

Václav Huml se je rodil leta 1880 v Berounu na Češkem. Praški konservatorij je končal v razredu Otakarja Ševčíka. Po odsluženju vojaškega roka je leta 1902 prevzel mesto prvega koncertnega mojstra Lvovske filharmonije, leta 1903 pa se javil na razpis za učitelja violine v Zagrebu. Ob pedagoškem delu v Glasbenem zavodu v Zagrebu je Huml sodeloval tudi v glasbenih predstavah zagrebške opere, v različnih komornih sestavih, priložnostno pa tudi kot solist. Leta 1940 je bil izbran za rednega profesorja Glasbene akademije. Zaslužen je za ustanovitev prvega profesionalnega orkestra v Zagrebu Zagrebački komorni orkestar, v katerem so igrali izključno njegovi učenci. Večkrat je bil kot profesor vabljen tudi v tujino, bil je član žirij na mednarodnem tekmovanju Henryk Wieniawski v Varšavi leta 1935 ter na mednarodnem tekmovanju za violino na Dunaju leta 1937. Po vojni je bil tudi član žirije mednarodnega tekmovanja Praška pomlad leta 1947. Ponujeno mu je bilo mesto profesorja na Akademiji glasbenih umetnosti v Pragi, vendar je ostal v Zagrebu. Po težki bolezni je tam umrl leta 1953 .

Karel Jeraj se je rodil leta 1874 na Dunaju očetu Johannu Jeraju iz Smlednika in materi Elizabeti Raček iz Brna. Oba sta izhajala iz glasbenih družin. Jeraj je iz violine diplomiral na dunajskem konservatoriju pri Josephu Hellmesbergerju. Teoretske predmete je študiral pri Antonu Brücknerju in Robertu Fuchsu. Po končanem študiju je poučeval violino na šoli Glasbene matice do leta 1895. V Londonu je v močni konkurenci postal koncertni vodja britanskega imperialnega glasbenega inštituta. Bil je tudi pianist-korepetitor in tesen prijatelj violinsta Georgesa Enesca, s katerim je nasopal po vsej Evropi. Leta 1912 se je zaposlil na zavodu za slepo mladino v Purkersdorfu, kjer je poučeval violino. Po prvi svetovni vojni se je z družino vrnil v Ljubljano, kjer se je kot učitelj violine zaposlil na šoli Glasbene matice in postal dirigent novoustanovljenega Orkestralnega društva. Kasneje je deloval kot profesor violine na državnem konservatoriju v Ljubljani in kot član orkestra Slovenskega narodnega gledališča. Umrl je leta 1951 v Ljubljani.

Vida Jeraj Hribar, hčerka violinista Karla Jeraja in pesnice Vide Jeraj (Franice Vovk) je bila rojena leta 1902 na Dunaju. Od šestega do dvanajstega leta, ko se je začela prva svetovna vojna, se je violino učila bolj občasno. Študij je nadaljevala na dunajskem glasbenem konservatoriju, kjer jo je poučeval profesor Egghart. S sedemnajstimi leti se je z družino preselila v Ljubljano, kjer jo je sprva poučeval Richard Zíka, kasneje pa Jan Šlaís, pri katerem je bila šest let. Po končanem študiju v Ljubljani je nadaljevala na pariškem konservatoriju pri Lucienu Capetu. Po študiju je poučevala v Celju, nato v glasbeni šoli Sloga in zatem na šoli Glasbene matice v Ljubljani. Solistično je nastopala s pianistom Danilom Švaro, s svojim očetom Karlom Jerajem in sestro violončelistko Oli Jeraj pa je delovala v Triu Jeraj. Po drugi svetovni vojni se je zaposlila najprej v Domovih igre in dela v Ljubljani, potem kot referentka za glasbo na ministrstvu za kulturo, v letih 1953-1963 pa je vodila novoustanovljeno Srednjo glasbeno šolo v Ljubljani. Pri devetdesetih je izdala knjigo spominov na življenje na Dunaju, v Parizu in Ljubljani z naslovom Večerna sonata. Prinesla ji je Levstikovo nagrado in naziv Slovenka leta. Leta 1995 ji je Srednja glasbena in baletna šola za njeno dolgoletno delo na tej ustanovi dodelila Škerjančevo nagrado. Umrla je leta 2002, stara 100 let. 
Antonín Kammel se je rodil leta 1730 v češkem mestu Bělec. Violino je študiral pri Giuseppeju Tartiniju v Padovi. Kot skladatelj se je osredotočil predvsem na instrumentalna dela, večinoma za godala. Umrl je leta 1784 v Londonu.

Anton Kučera se je rodil leta 1872 v češkem mestu Swinař. Končal je kompozicijsko smer praškega konservatorija. Umrl je leta 1934.

Jaroslav Kocían se je rodil leta 1883 v mestu Ústí nad Orlicí. Najprej ga je poučeval oče, v nadaljnje šolanje pa ga je zaupal Bennewitzevemu učencu Josefu Zabrodskemu, ki je bil izvrsten violinist. Leta 1896 se je vpisal na praški konservatorij v razred profesorja Otakarja Ševčíka. Ta je bil nad njegovim talentom zelo navdušen. Iz violine je diplomiral 5. 7. 1901, dan kasneje pa še iz kompozicije v razredu Antonína Dvořáka. Po študiju je ogromno koncertiral in postal slaven violinist tistega časa. Leta 1921 je na praškem konservatoriju postal asistent profesorja Otakarja Ševčíka, leta 1924 pogodbeni profesor in pet let kasneje redni profesor mojstrske šole, na kateri je deloval vse do leta 1943. Umrl je leta 1950 v Pragi.

Ferdinand Lachner je bil rojen leta 1856 v Pragi. Njegov prvi učitelj violine je bil Erazim Laub (1794-1865), ki je poučeval tudi sina Ferdinanda Lauba, enega najslavnejših čeških violinistov vseh časov. Praški konservatorij je Lachner končal v razredu Antonína Bennewitza. Po diplomi je obiskoval še orglarsko šolo in končal študij kompozicije v razredu Zdeňka Fibicha. Leta 1879 je postal koncertni mojster v Vroclavu, čez eno leto pa še v Varšavi, kjer je živel do leta 1883. Povabljen je bil k praškemu narodnemu gledališču in leta 1888 postal njegov koncertni mojster. Pozneje je postal tudi profesor na praškem konservatoriju.Umrl je leta 1910 v Pragi.

Jan Mařák se je rodil leta 1870 v Dunakészu na Madžarskem. Z dvanajstimi leti se je vpisal na praški konservatorij v razred Antonína Bennewitza. Konservatorij je končal že leta 1888, a je tam ostal še eno leto, na dodatnem izpopolnjevanju. Leta 1891 je postal koncertni mojster v Kaliningradu, leta 1892 pa v orkestru Narodnega gledališča v Pragi. Leta 1897 je bil imenovan za profesorja violine na praškem konservatoriju, kjer je ostal vse do svoje smrti leta 1932. Podobno kot Otakar Ševčík v Písku, je imel tudi Mařák svoj krožek za tujce v Pragi. Med njegovimi tujimi učenci je bila tudi Paganinijeva vnukinja Andreina Paganini. Mařákov najuspešnejši učenec pa je bil zagotovo Váša Př́́hoda, ki ga je poučeval kar deset let. Mařák je umrl leta 1932 v Pragi.

Gašpar Mašek se je rodil leta 1794 v Pragi. Poučeval ga je oče Vincent Mašek, ki je bil klavirski virtuoz in pedagog. Študij glasbe je nadaljeval na praškem konservatoriju. Leta 1812 je postal kapelnik vojaške godbe 8 . divizije češke armade, leta 1819 pa kapelnik Stanovskega gledališča v Gradcu, kjer je spoznal Amalijo Horny, s katero se je kmalu poročil. Preselila sta se v Ljubljano, kjer je Mašek postal vodja orkestra Filharmonične družbe in njenega zbora. Bil je tudi kapelnik v ljubljanskem Stanovskem gledališču. Umrl je leta 1873 v Ljubljani.

Moritz (Mořic) Mildner se je rodil leta 1812. Violino je študiral na praškem konservatoriju v razredu W. F. Pixisa, ki ga je kasneje na konservatoriju tudi nasledil. V letih 1843-1864 je igral v godalnem kvartetu skupaj z Brücknerjem, Webrom in Wagnerjem ter v klavirskem triu s Smetano 
pri klavirju. Ustvaril je ogromno pomembnih violinistov, ki so se zapisali v violinsko zgodovino. Umrl je leta 1865 .

Gustav Moravec se je rodil leta 1838 na Češkem. Na šoli Filharmonične družbe je deloval 46 let kot učitelj petja, klavirja in violine. V letih 1871-1892 je poučeval tudi na ljubljanskem učiteljišču. Redno je igral v orkestru in kot violist $\mathrm{v}$ različnih komornih zasedbah.

Vitězslav (Viktor, Roman) Moser se je rodil leta 1864 v Sušicah na Češkem, kjer je dobil prvo violinsko znanje pri Františku Neumannu. Študij violine je nadaljeval na praškem konservatoriju v razredu Ferdinanda Lachnerja, študij kompozicije v razredu Zdeňka Fibicha. Od leta 1885 je bil član orkestra Narodnega gledališča v Pragi. V letih 1888-1891 je deloval kot učitelj violine na šoli Glasbene matice v Ljubljani, v letih 1891-1903 pa je bil profesor violine na zagrebškem konservatoriju. Tam je napisal tudi teoretično-praktično violinsko šolo. V letih 1920-1933 je deloval v Plznu kot violinski pedagog na glasbeni šoli Bedřícha Smetane ter bil član Plznske filharmonije. Umrl je leta 1939 v Plznu.

Anton Nedvěd je bil rojen leta 1829 v Hořovicah. V otroštvu ga je violino, klavir in petje poučeval Antonín Slavík. Vpisal se je na praški konservatorij, kjer je diplomiral iz violine in petja. Violino je končal v razredu Moritza Mildnerja. Kratek čas je kot pevec deloval v operi v Brnu, potem pa prišel v Ljubljano. Na različnih glasbeno-vzgojnih zavodih je poučeval različne predmete, posvečal pa se je predvsem vokalni glasbi. Umrl je leta 1896.

Leon Pfeifer se je rodil leta 1907 v Ljubljani. Do leta 1933 ga je violino poučeval Jan Šlaís, pri katerem je končal konservatorij. Zatem se je dve leti izpopolnjeval pri Jaroslavu Kocíanu. Od leta 1935 do 1951 je bil učitelj violine na Glasbeni matici in Srednji glasbeni šoli v Ljubljani. Od leta 1951 je bil profesor na Akademiji za glasbo, v letih 1970-1974 tudi rektor. Igral je v vseh ljubljanskih simfoničnih orkestrih, ustanovil je tudi zelo uspešni Ljubljanski godalni kvartet. Iz njegove šole so izšli: Rok Klopčič, Olga in Sabina Skalar, Tomaž Lorenz, Zdravko Cobenzl, Vladimir Škerlak, Igor Ozim ter drugi. Umrl je 25. avgusta 1986 v Ljubljani.

Mavricij Poehm je v Novo mesto prišel s Češkega. Bil je organist in odličen glasbenik, gvardijan tamkajšnjega samostana, profesor na samostanski gimnaziji ter osrednja novomeška osebnost $v$ drugi polovici 18. stoletja.

Uroš Prevoršek je bil rojen leta 1915 v Ljubljani. Prvo znanje violine je dobil zasebno, potem je študiral violino na konservatoriju v Ljubljani (1928-1937) pri Janu Šlaísu. Poleg violine je študiral še kompozicijo in dirigiranje. Zatem je odšel v Milano, kjer je zasebno študiral violino pri Albertu Poltronieriju in leta 1939 diplomiral na konservatoriju Giuseppe Verdi. Po vrnitvi v domovino je postal koncertni mojster radijskega orkestra v Beogradu, kjer je vodil tudi radijski godalni kvartet in prirejal javne komorne koncerte. Po osvoboditvi leta 1945 je postal dirigent radijskega orkestra v Ljubljani, od leta 1946 pa profesor teoretičnih predmetov na srednji stopnji Akademije za glasbo. Veliko je nastopal kot violinist, pa tudi njegov kompozicijski opus zajema največ violinskih skladb. Umrl je leta 1998. 
Vladimir Prinčič se je rodil leta 1888 v Vipolžah na Goriškem, kjer je obiskoval osnovno šolo. Prvo glasbeno znanje mu je dala njegova sestra. V Gorici se je v letih 1902-1904 učil violino in klavir pri stolnem organistu Francu Setničarju. V Trstu ga je violino in violo učil Petr Teplý. Od leta 1922 je kot violist sodeloval v Orkestralnem društvu GM v Ljubljani, kjer je na konservatoriju pri Lucijanu Mariji Škerjancu študiral kompozicijo.

Váša Př́íhoda se je rodil leta 1900 v mestu Vodňany na jugu Češke, od koder se je s svojo družino preselil v Prago. Po desetih letih marljivega študija pri Janu Mařáku se je iz čudežnega otroka razvil v izvrstnega violinista, zato je bil priljubljen povsod po svetu. V letih 1936-1938 in 1941-1943 je uspešno izvajal poletno šolo na salzburškem Mozarteumu, leta 1944 je poučeval na Visoki glasbeni akademiji v Münchnu, leta 1949 pa znova v Salzburgu. Leto kasneje je bil povabljen na Akademijo za glasbo in upodabljajoče umetnosti na Dunaj, sprva kot pogodbeni, od leta 1951 in vse do svoje smrti pa kot redni profesor. Njegovo pedagoško delo je bilo zelo uspešno. K njemu so prihajali violinisti z vsega sveta. Snemal je za Polydor, hkrati pa je tudi sam napisal kar nekaj violinskih skladb: Polonezo, Slovanske melodije, Sonato za violino in klavir, Koncert za violino in orkester ter razna druga virtuozna dela. Pred svojo smrtjo je Češki republiki prodal vse svoje dragocene stradivarke, imenovane Camposelice. Umrl je leta 1960, z njegovo smrtjo pa se je končalo obdobje slavne češke violinske umetnosti konca devetnajstega in prve polovice dvajsetega stoletja.

Taras Poljanec se je rodil leta 1908. Violino ga je sprva poučeval Karel Jeraj, konservatorij pa je končal pri Rudolfu Reissigu v Pragi. Deloval je solistično, pedagoško in v raznih komornih sestavih.

Rudolf Reissig je bil rojen leta 1874. Na praškem konservatoriju je bil učenec Antonína Bennewitza. Sprva je poučeval na brnskem konservatoriju, v šolskem letu 1919/1920 pa je začel poučevati na praškem konservatoriju. Umrl je leta 1939.

Karl Rohm se je rodil 5. 5. 1803 v občini Kneschitz bei Kaaden. Umrl je 14. 5. 1877 v Žluticah (Matrice iz arhivov v Plzňu in Litoměricah). Preden je prišel v Žlutice je deloval kot kapelnik v Dresdnu.

Karlo Rupel se je rodil 1907 v Trstu. Violino so ga poučevali Fran Topič, Karlo Sancin in Jan Šlaís, pri katerem je končal tudi ljubljanski konservatorij. Zatem se je izpopolnjeval na zasebni mojstrski šoli profesorja Otakarja Ševčíka in na visoki šoli za glasbo v Parizu pri Jacquesu Thibaultu. Leta 1939 je bil imenovan za docenta Glasbene akademije v Ljubljani. Leta 1945 je postal izredni, štiri leta kasneje pa redni profesor Akademije za glasbo. V letih 1949-1951 je bil rektor Akademije za glasbo. Solistično je koncertiral v mnogih mestih po svetu, posvečal se je tudi komorni glasbi. Izvedel in posnel je tudi mnogo takratnih slovenskih violinskih novitet. Umrl je po dolgi in zelo težki bolezni leta 1968. Njegovi učenci so bili: Dejan Bravničar, Francka Ornik-Rojc, Mirko Petrač in Ciril Veronek.

Ivan Karel (Karlo) Sancin se je rodil leta 1893 v Škednju pri Trstu. Z glasbenim šolanjem je začel zasebno, najverjetneje pri Josipu Michlu v Gorici. Študij violine je nadaljeval na tržaškem konservatoriju Giuseppe Verdi v razredu Augusta Jankoviča (Jancovich). Po koncu vojne, leta 1918, je postal član ljubljanskega opernega orkestra in pedagog na ljubljanski Glasbeni matici. Bil je soustanovitelj in član slovitega Zíka kvarteta. Leta 1922 je postal ravnatelj glasbene šole v Celju, kjer je ostal do 
leta 1941. Tam je izboljšal kakovost poučevanja violine, kar je dokazal s svojim učencem Miranom Vihrom. V tem obdobju se je izpopolnjeval tudi pri Václavu Humlu v Zagrebu. Leta 1941 so ga nacistični okupatorji izgnali v Ljubljano, kjer je prebil vojna leta kot član orkestra ljubljanske opere in kot učitelj violine na šoli Glasbene matice. Po vojni se je vrnil v rodni Trst. Ukvarjal se je tudi z izdelovanjem violin; v Nemčiji je patentiral posebno obliko podbradnika. Bil je tudi skladatelj, njegovo najbolj znano delo je Celjska suita. Umrl je leta 1975 v Ljubljani.

Jan (Hanuš, Hans) Sitt, brat violinista Antonína Sitta, se je rodil leta 1850. Študij violine je končal na praškem konservatoriju v razredu Moritza Mildnerja in Antonína Bennewitza. Kot koncertni mojster je deloval v Vroclavu, v Pragi in drugod. Od leta 1883 je bil profesor violine na leipziškem konservatoriju. Proslavil se je kot violinist in kot član Brodsky kvarteta. Napisal je tudi nekaj violinskih del. Umrl je leta 1922.

Antonín Slavík se je rodil leta 1782 v Hořovicah Josefu in Evi Slavík (rojeni Kratochvílová). Najprej ga je poučeval stric Jan Slavík, ki je bil znan glasbenik in skladatelj (njegova dela hrani arhiv narodnega muzeja v Pragi). Antonín Slavík je kmalu postal domači učitelj pri grofu Evženu z Vrbna. Obiskoval je tudi učiteljsko pripravnico v Breznici in se izpopolnjeval pri P. Navagiu Šafař́́ku. Leta 1800 se je vrnil v Hořovice, kjer je s pomočjo grofa Evžena z Vrbna leta 1805 postal učitelj na novoustanovljeni šoli v Hořovicah. Bil je odličen glasbenik, ki je obvladal več instrumentov, predvsem orgle, violino in violončelo. V svojem okolju je močno zaznamoval celotni glasbeni razvoj, saj je glasbeno poučeval svoje vrstnike, meščane in tudi preproste ljudi. Gojil pa je tudi komorno glasbo, predvsem godalni kvartet, ki je vsak teden izvajal dela iz klasicističnega repertoarja pri grofovem nadzorniku Josefu Laboru (1790-1872), ki je bil tudi sam glasbenik (Laborjev sin Josef Labor mlajši (1842-1924) je kljub slepoti, ki ga je doletela že v otroštvu, postal izvrsten glasbeni pedagog in skladatelj. Med njegovimi slavnimi učenci je bil tudi Arnold Schönberg). Antonín Slavík se je poročil z Barbaro Krasovo, ki mu je rodila devet otrok. Svojega prvorojenca Josefa Slavíka (1806-1833) je začel poučevati, ko je imel ta štiri leta, in ga učil osem let. Josef Slavík danes velja za enega največjih čeških violinistov vseh časov. Antonín Slavík je umrl leta 1853 v Hořovicah.

Jan Slavík je bil rojen leta 1787 v Novem Stupovu na Češkem. Šolal se je na Češkem in bil tam nekaj časa učiteljski pripravnik. Leta 1814 je prišel na Slovensko, kjer je poučeval v več mestih. Umrl je leta 1842 v Postojni.

Franz Sokol se je rodil leta 1779 v mestu Sadska na Češkem. V letih 1812-1816 je bil učitelj glasbe v Celovcu. Šest let je bil polkovni kapelnik, izkazal pa se je tudi kot skladatelj. Kot član Filharmonične družbe je nastopal v orkestru in solistično kot klarinetist, čelist in pevec. Umrl je leta 1822 v Ljubljani.

Fran Stanič je bil rojen leta 1893 v Brežicah. Leta 1898 se je z družino preselil v Bessemer (ZDA), a se je po očetovi smrti vrnil v domovino. Violino se je učil pri Saši Šantlu in Augustu Jankoviču na konservatoriju Giuseppe Verdi v Trstu. Leta 1933 je diplomiral na ljubljanskem konservatoriju pri Janu Šlaísu. Violino je poučeval v letih 1925-1927 na Glasbeni matici v Novem Mestu, 19271941 v Ljubljani, 1930-1937 na nižji in srednji stopnji državnega konservatorija, 1940-1946 na državnem učiteljišču, 1946-1953 na Srednji glasbeni šoli, od leta 1946 do 1954 pa je bil profesor 
in ravnatelj na Glasbeni šoli Center. Igral je v več orkestrih ter napisal kar nekaj violinskih šol in skladb. Njegova učenca sta bila hčerka Jelka Stanič in Dejan Bravničar. Umrl je leta 1979 v Ljubljani.

Jelka Stanič se je rodila leta 1928 v Novem Mestu. Violino sta jo poučevala oče Fran Stanič in Jan Šlaís. Študij je nadaljevala pri Václavu Humlu na Glasbeni akademiji v Zagrebu in Ernestu Moravcu v Salzburgu. Svojo umetniško kariero je začela leta 1946 na koncertu Slovenske filharmonije v Ljubljani. V Jugoslaviji je bila prva, ki je izvedla Bartokov Koncert za violino in orkester št. 2. Ob solistični dejavnosti je bila v letih 1957-1967 tudi solistka v ansamblu Zagrebških solistov, ki je uspešno nastopal povsod po svetu. Kasneje je postala članica orkestra Radio-Saarland v Saarbrücknu. Trenutno živi v Saarbrücknu v Nemčiji.

Georg Stiaral se je rodil leta 1824 v mestu Zadní Trebaň na Češkem.

Stĕpán Suchý se je rodil leta 1872 v Aradu v Uhráhu. V igranju na violino je tako hitro napredoval, da je že s štirinajstimi leti postal član orkestra Narodnega gledališča v Brnu, čez štiri leta koncertni mojster in vodja orkestra. Leta 1893 je vstopil na praški konservatorij v razred prof. Otakarja Ševčíka, kjer je leta 1897 diplomiral kot najboljši učenec. Kmalu po diplomi na konservatoriju je z velikim uspehom igral kot solist na koncertih v Pragi, na Dunaju, Berlinu in Münchnu. Leta 1897 je Suchý na konservatoriju nastopil kot asistent, leta 1902 je bil imenovan za profesorja. Umrl je leta 1920 v Pragi.

Otakar Ševčík se je rodil leta 1852 v Horažd'ovicah, kjer ga je najprej poučeval njegov oče, ki je bil violinist in organist. Študij je nadaljeval na praškem konservatoriju, najprej nekaj mesecev pri Antonínu Sittu, pozneje pa pri Antonínu Bennewitzu. Po končanem študiju je oktobra 1870 nastopil kot koncertni mojster in učitelj na Mozarteumu v Salzburgu. Čeprav so mu bili takratni kritiki kot violinskemu koncertantu zelo naklonjeni, je bil sam prepričan, da mu do odlične violinske tehnike še veliko manjka. Zaradi tega je začel pisati svojo violinsko metodo. Bil je koncertni mojster nekaterih takrat priznanih orkestrov, leta 1875 pa je postal profesor violine na kijevskem konservatoriju. Na začetku šolskega leta 1892/1893 je bil imenovan za profesorja violine na praškem konservatoriju. Čez nekaj let je bila na konservatoriju uradno sprejeta njegova violinska metoda. Ker je bilo zanimanje tujcev zanjo tako veliko, je ustanovil zasebno šolo, ki se je imenovala Kolonija za tujce. Ta je bila sprva v Pragi, od leta 1904 pa v Prachaticah. Zaradi težav z zavistno konkurenco konservatorija se je pomladi 1907 s svojo Kolonijo za tujce ustalil v Písku. Februarja 1909 je bil imenovan za predstojnika mojstrske violinske šole na Akademiji za glasbo na Dunaju, kjer je ostal do konca prve svetovne vojne. Po koncu vojne je na Dunaju nehal poučevati. Leta 1918 je bil imenovan za častnega člana profesorskega zbora praškega konservatorija, $v$ šolskem letu 1919/1920 pa je bil na tamkajšnji ustanovi imenovan za profesorja novoustanovljene mojstrske šole za violino. Po daljši bolezni je umrl leta 1934 v Písku. Ustvaril je vrsto najuspešnejših violinistov tistega časa, ki so delovali povsod po svetu in tako razširili njegovo violinsko šolo.

Jan Šlaís se je rodil leta 1893 v Pragi. Leta 1913 je končal študij violine pri profesorju Stěpánu Suchýju na praškem konservatoriju. Po letu 1913 je poučeval violino v Moskvi in sprejel službo drugega koncertnega mojstra v tamkajšnjem Umetniškem gledališču. Po izbruhu vojne leta 1914 
je postal koncertni mojster v Veliki operi Zimina, hkrati pa je sodeloval pri velikih simfoničnih koncertih pod vodstvom Kusewickega in Glazunova. Tam je ostal do leta 1919, ko se je vrnil v Prago, kjer je igral v orkestru Narodnega gledališča. Istega leta je nastopil kot učitelj violine na šoli mariborske Glasbene matice, kjer je spoznal svojo kasnejšo ženo Růženo Deylovo Šlaísovo. Naslednje leto (1920/1921) je zapustil Maribor in nadaljeval študij na mojstrski šoli profesorja Otakarja Ševčíka v Pragi. Nekateri zanesljivi viri (Rok Klopčič, ustni vir, in knjiga Večerna sonata Vide Hribar Jeraj) pričajo, da je bil Šlaís tudi učenec Jacoba Grüna. 15. septembra 1921 se je vrnil na Slovensko, tokrat v Ljubljano, kjer je postal profesor violine na konservatoriju. Leta 1939 je bil imenovan za izrednega profesorja na novi glasbeni akademiji. Od prihoda v Ljubljano je s svojo ženo tudi koncertiral. Na glasbeni akademiji v Ljubljani je deloval do leta 1946, ko se je dokončno vrnil v svojo prvo domovino - Češko. Tam je bil najprej profesor na praškem konservatoriju, od leta 1952 pa na Janáčkovi Akademiji glasbenih umetnosti v Brnu. Umrl je leta 1975.

Václav Talich se je rodil leta 1883 v Kroměřížu na Češkem. Violino je študiral na praškem konservatoriju v razredu Jana Mařáka in Otakarja Ševčíka. Leta 1903 je postal koncertni mojster Berlinske filharmonije, ko ji je dirigiral Arthur Nikisch. Zatem je kot koncertni mojster deloval v Odesi in kot violinski učitelj v Tbilisiju. Leta 1906 se je vrnil v Prago, kjer je kratek čas deloval kot dirigent. Leta 1908 je prišel v Ljubljano, kjer je vodil novoustanovljeni orkester Slovenske filharmonije. Zatem se je posvetil študiju dirigiranja v Leipzigu in se po študiju vrnil v Prago, kjer zelo uspešno deloval kot dirigent. Umrl je leta $1961 \mathrm{v}$ Berounu.

Petr Teplý se je rodil leta 1871 v Pragi. Znan je bil tudi pod imenom Pietro Caldo. Končal je praški konservatorij (1882-1888) v razredu Antonína Bennewitza in igral violino v različnih orkestrih v Avstriji, Nemčiji, na Švedskem in v Rusiji. V Pragi je bil prvi violinist v nemškem gledališču. Ko je odslužil vojaški rok, je prevzel mesto kapelnika pri 40. in nato 97. pehotnem polku v Trstu, kjer je na Glasbeni matici poučeval violino. Leta 1912 je prevzel vodstvo Slovenske filharmonije, nato je bil v letih 1925-1931 poveljnik vojaške glasbene šole v Pragi. Umrl je leta 1964 v Pragi.

Johann Baptist Vaňhal (tudi Wanhal, Wanhal, Wanhall) se je rodil leta 1739 v Nechanicah na Češkem. Violinskih virtuoznosti in skladanja koncertov ga je poučeval Mathias Nowak. Njegov opus je zelo bogat in raznolik, napisal je tudi mnogo del za violino. Umrl je leta 1813.

Josip (Josef) Vedral se je rodil leta 1872 v Stavropolu v Rusiji. Praški konservatorij je končal v razredu Antonína Bennewitza. Leta 1895 je na Glasbeni matici v Ljubljani nasledil violinskega pedagoga Karla Jeraja, kjer je začel poučevati violino kot glavni ter klavir kot stranski predmet. Umrl je leta 1929 v Ljubljani, pokopan je na ljubljanskih Žalah.

Miran Viher se je rodil leta 1919 v Slovenskih Goricah. Violino se je začel s štirimi leti učiti pri svojem očetu. Ko je dopolnil šest let, je nadaljeval svoj glasbeni pouk na šoli Glasbene Matice v Celju pri profesorju Karlu Sancinu. S štirinajstimi leti je krajši čas študiral tudi pri Otakarju Ševčíku, s petnajstimi leti pa je postal učenec Václava Humla na zagrebški glasbeni akademiji. Po končanem študiju na glasbeni akademiji v Zagrebu je obiskoval mojstrski razred pri Váši Příhodi v Salzburgu in Münchnu. Vse do leta 1943 je igral v beograjskem simfoničnem orkestru, nato ga je pot zanesla v Italijo. Po koncu vojne se je vrnil v Jugoslavijo, kjer je poučeval na državni 
glasbeni šoli (kraj iz arhivov ni razviden) in na zagrebškem glasbenem konservatoriju. Leta 1952 je bil zaradi političnih razlogov aretiran, zato je Jugoslavijo zapustil. V letih 1952-1956 je poučeval v Münchnu, kjer je bil tudi koncertni mojster v bavarskemu simfoničnemu orkestru. Po štirih letih je emigriral v Združene države Amerike; tam je bil v letih 1956-1969 član filharmoničnega orkestra v Buffalu (Buffalo Philharmonic Orchestra), v katerem je igral prvo violino, nato je bil kratek čas član princetonskega komornega orkestra (Princeton Chamber Orchestra), od leta 1970 pa član opernega gledališča v Saint Louisu (The Opera Theatre of Saint Louis). Za ta orkester je leta 1981 napisal violinski koncert, ki ga je 18.2. $1984 \mathrm{~s}$ prej omenjenim orkestrom izvedel Silvian Iticovici. Viher je poučeval violino na Webstrovi univerzi in zasebno. V času svojega delovanja je tudi komponiral in napisal več del. Preživela partitura je Sonata za dve violini, nekaj manjših del za violino solo in Suita jugoslovanskih pesmi in plesov za oboo in godala. Najbolj znano delo je že prej omenjeni Violinski koncert. Umrl je leta 2002 v Združenih državah Amerike.

Arturo Vram se je rodil leta 1860 v Trstu. Violino je študiral pri Josefu Hellmesbergerju na dunajskem konservatoriju, kjer je diplomiral leta 1882. Leta 1887 je v Trstu ustanovil violinsko šolo, na kateri je ustvaril kar nekaj izvrstnih violinistov. Umrl je leta 1938 v Trstu.

Josef Wiedmann se je rodil leta 1828 v Kvitkovu na Češkem, umrl je leta 1918.

Richard Zíka se je rodil leta 1897. Violino se je učil pri svojem očetu Karlu Zíki in stricu Františku Zíki, učencu Otakarja Ševčíka. Konservatorij je končal v razredu Štěpána Suchýja. Okoli leta 1917 je v avstrijskem Judenburgu spoznal slovenskega pianista Janka Ravnika, s katerim se je odločil oditi v Ljubljano. Leta 1918 se je Zíka kot učitelj zaposlil na šoli GM in kot koncertni mojster Slovenskega narodnega gledališča. Ustanovil je Zíka kvartet, ki se je kasneje preimenoval v Praški kvartet in postal svetovno znan. Leta 1946 je bil Zíka imenovan za profesorja violine na akademiji glasbenih umetnosti v Pragi. Med drugim je napisal tudi šest capricciev za violino solo. Umrl je leta 1947. 


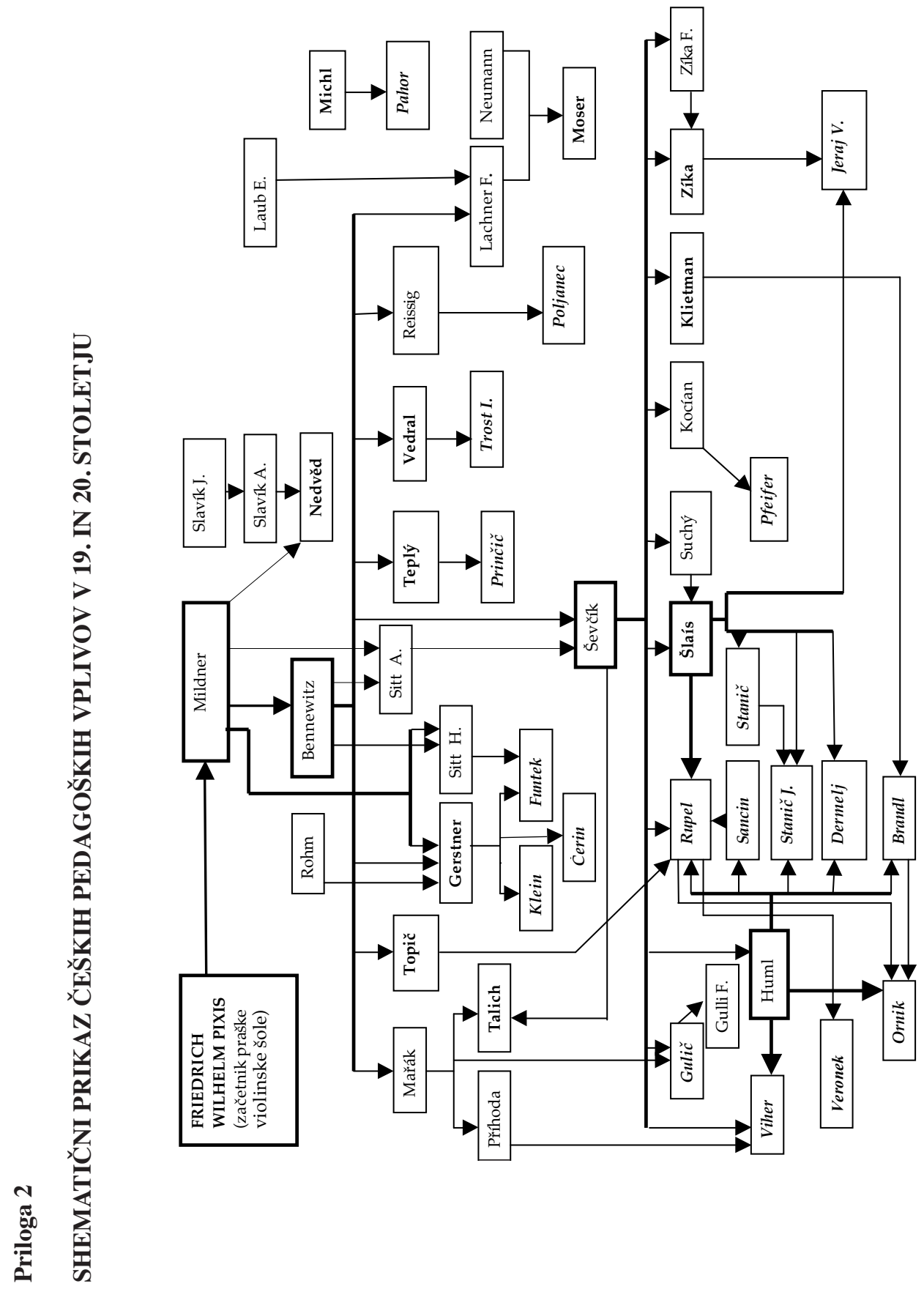




\section{Priloga 3}

\section{IZBOR SLIKOVNEGA GRADIVA}

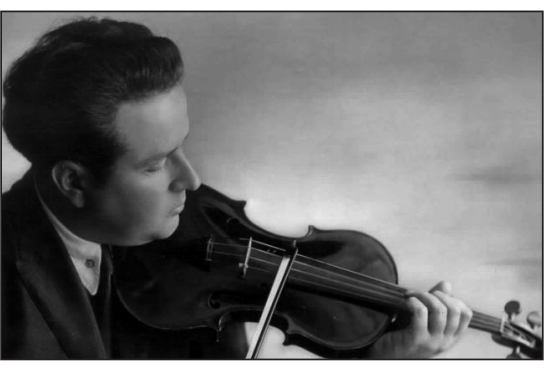

Slika 1

Karel Sancin (1893-1975). Slika iz leta 193? (sliko hrani Narodna in univerzitetna knjižnica v Ljubljani; z dovoljenjem).

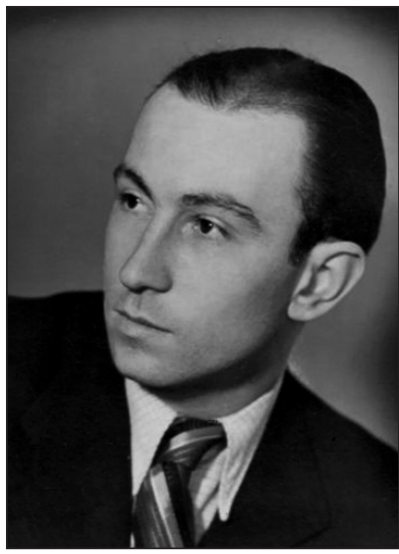

Slika 3

Albert Dermelj (1912-1986). Slika iz leta 1939 (sliko hrani Narodna in univerzitetna knjižnica v Ljubljani; z dovoljenjem).

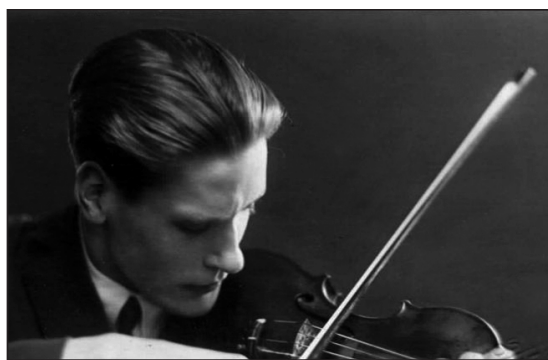

\section{Slika 2}

Karlo Rupel (1907-1968). Slika iz leta 19?? (sliko hrani Narodna in univerzitetna knjižnica v Ljubljani; z dovoljenjem).

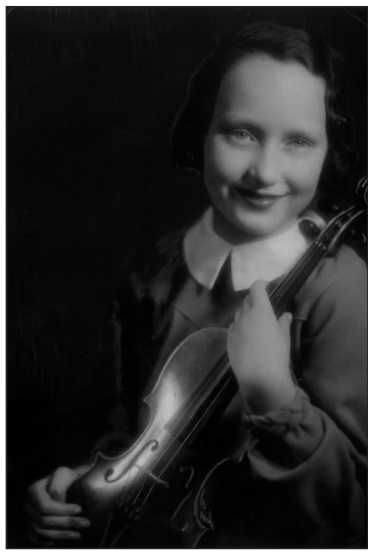

Slika 4

Jelka Stanič (1928- ). Slika iz leta 1937 (sliko hrani Narodna in univerzitetna knjižnica v Ljubljani; z dovoljenjem). 


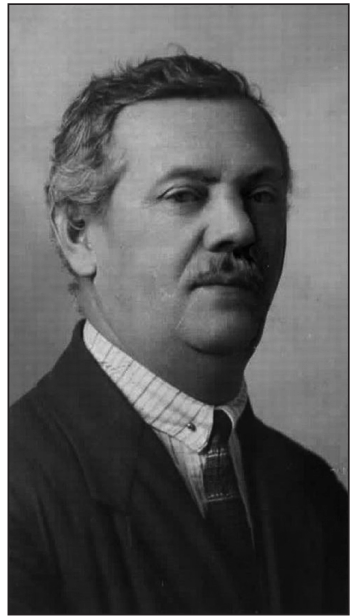

Slika 5

Josip Vedral (1872-1929). Slika iz leta 192? (sliko hrani Narodna in univerzitetna knjižnica v Ljubljani; z dovoljenjem).

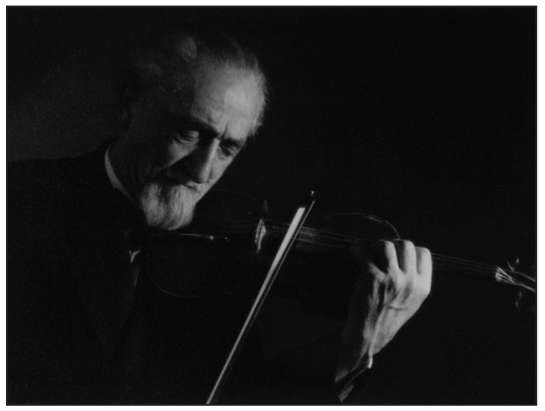

\section{Slika 7}

Karel Jeraj (1874-1951). Slika iz leta 194? (sliko hrani Narodna in univerzitetna knjižnica v Ljubljani; z dovoljenjem).

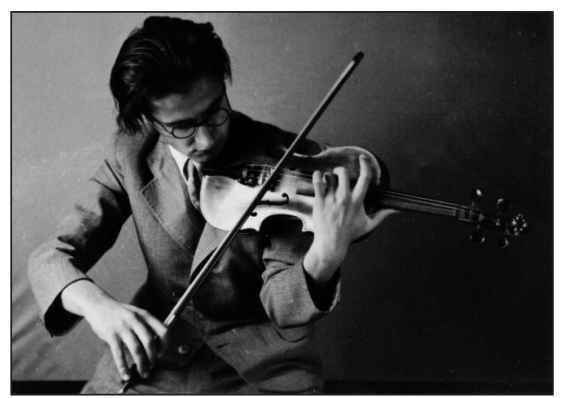

\section{Slika 6}

Miran Viher (1919-2002). Slika iz leta 1941 (sliko hrani Narodna in univerzitetna knjižnica v Ljubljani; z dovoljenjem).

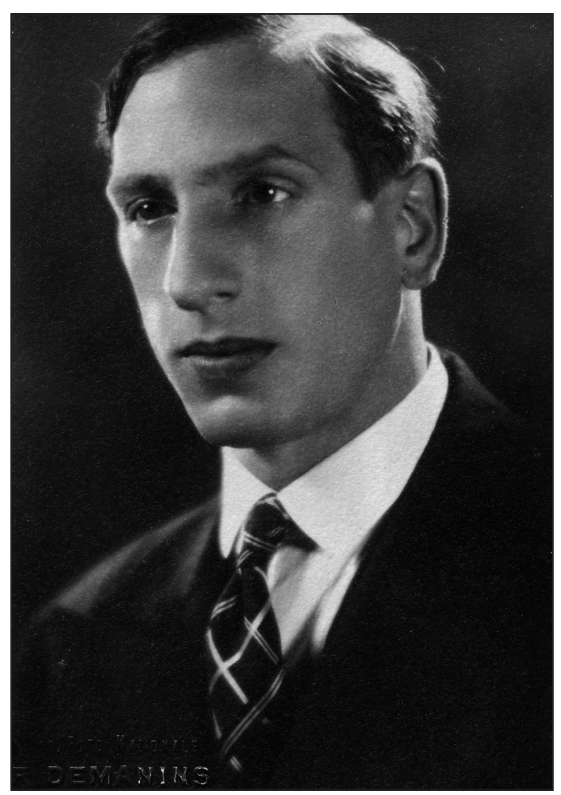

\section{Slika 8}

Fran Gulič (1901-1973). Slika iz leta 192? ( $\mathrm{z}$ dovoljenjem lastnice slike Giuliane Gulli). 


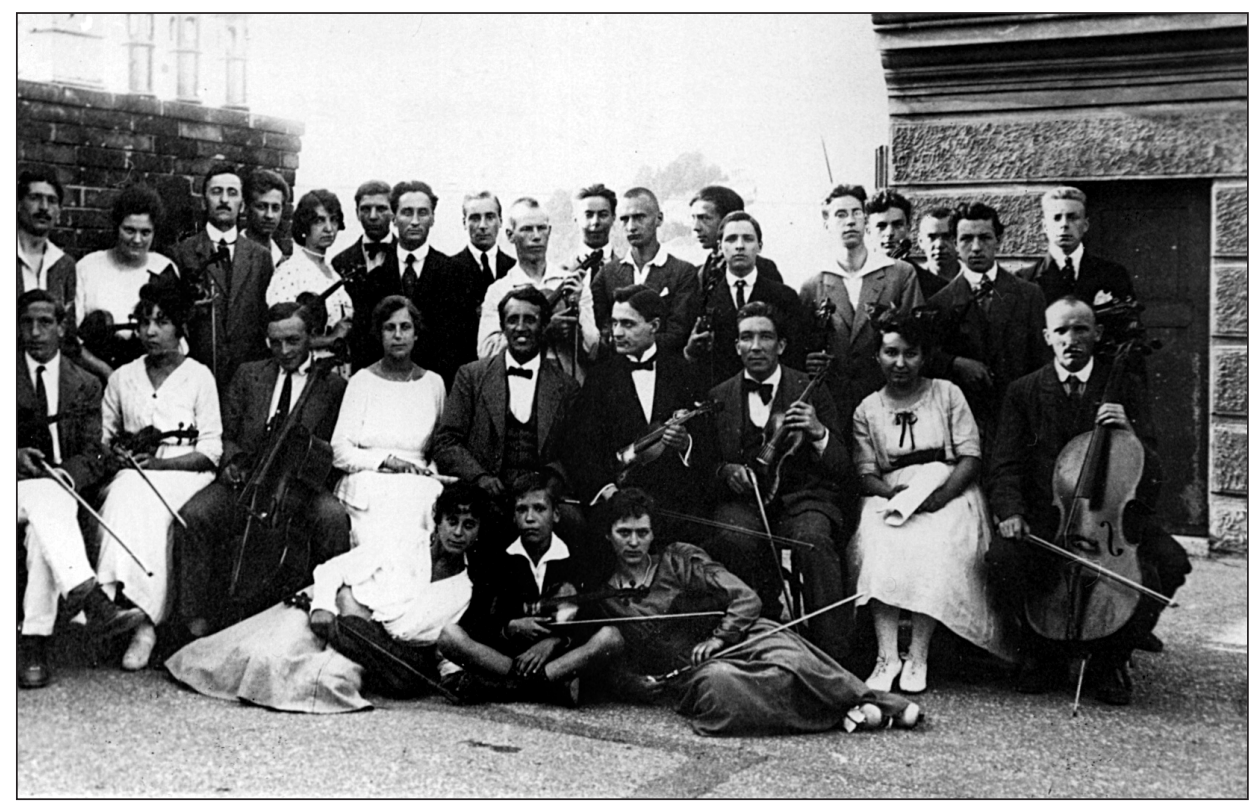

Slika 9

Orkester Glasbene matice v Trstu tik pred požigom Narodnega doma. Prvi z leve proti desni sedi Fran Gulič, peti z leve proti desni sedi Fran Topič in v prvi vrsti na sredini sedi na tleh mladi Karlo Rupel ( $\mathrm{z}$ dovoljenjem Fotografska arhiva Narodne in študijske knjižnice - Trst). 


\title{
IN SEARCH OF ITS TRUE IDENTITY: \\ CZECH VIOLINISTS AS THE MAIN CREATORS \\ OF VIOLINISM IN SLOVENIAN LANDS
}

\begin{abstract}
Summary
Violinism, which left its mark on subsequent generations of violinists, did not develop in Slovenia until the beginning of the nineteenth century, when the first music schools were founded. Some preliminary steps in this direction were made by the Public Music School (Javna glasbena šola), though the quality of its violin teaching remained elementary. Greater success was achieved by the Philharmonic Society (Filharmonična družba), which accepted accomplished Czech violin virtuosos among its teaching staff. The most credit for educational progress may be attributed to Johann (Hans) Gerstner, who added an extensive violin concert repertoire to the Philharmonic Society's concert programme, taught thousands of pupils, and compiled a curriculum for violin teaching that was also used by the Music Society (Glasbena matica). The founding of the Music Society in 1882 spawned the first generation of Slovenian violinists, who were later active as concert performers and excellent violin teachers. The majority of them were taught by the Czech violin teacher Jan Šlaís, who taught in Slovenia for 25 years and had a profound impact on the development of Slovenian violinism in the first half of the twentieth century. This period of Slovenian violinism was also marked by the Czech violinist and teacher Otakar Ševčík and his studies on violin methods. Ševčík's methods were brought to this area through his "missionary" violinists, who taught in the region. The Ševčík violin method was employed by most teachers of that time, and many Slovenians were encouraged to follow its example and establish the first Slovenian violin schools. The Czech violinists were active not only in education and interpretation; their broad knowledge of violinism was also reflected in Slovenian musical creation. The works composed under their influence enriched the violin repertoire and resulted in the proliferation of violin pieces in the concert programs of that era. Furthermore, Czech influences made a significant contribution to the development of symphony orchestras and the establishment of the Slovenian Philharmonic, initially led by Czech conductor Václav Talích. His successful management of the Philharmonic influenced the subsequent development of Slovenian violinism. Encouraged by the accomplishments of the newly-formed orchestra, many music education institutions engaged in the systematic tutoring of younger orchestral performers. As the numbers of Slovenian orchestra members increased, Czechs no longer constituted the majority as had previously been the case. By the end of the Second World War, Slovenian violinists had replaced their Czech peers in education as well.
\end{abstract}

